
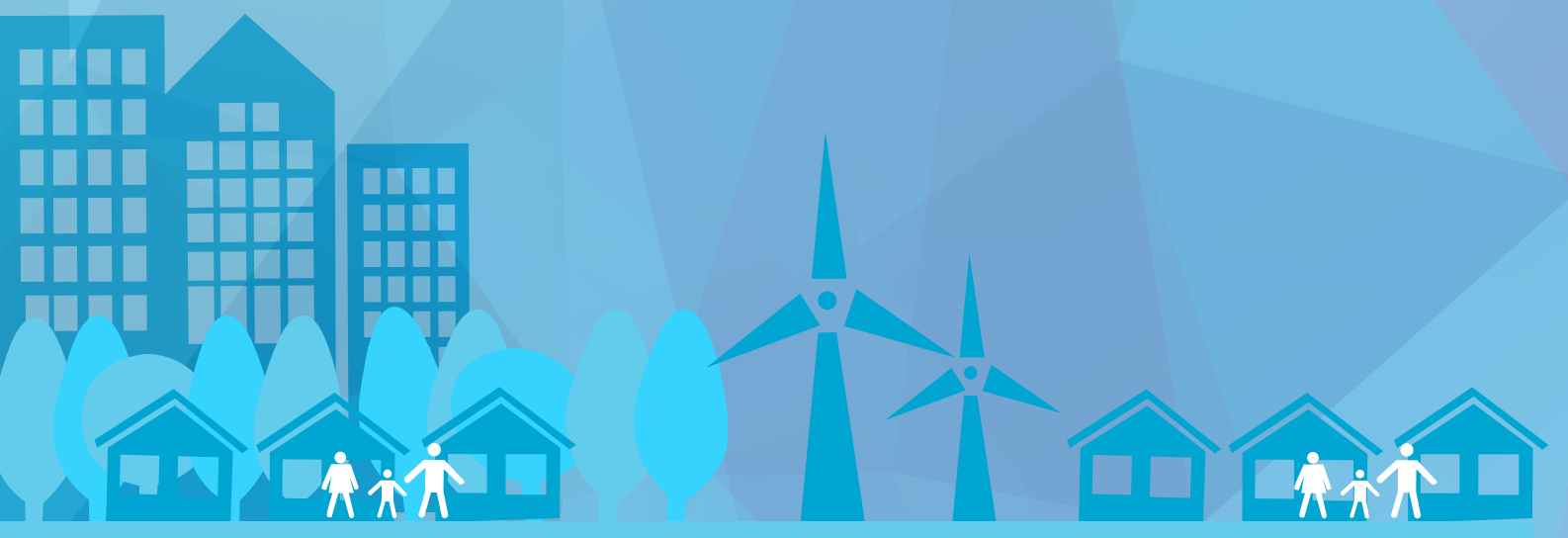

\title{
WATER SAFETY PLANNING FOR URBAN WATER UTILITIES Practical Guide for ADB Staff
}




\section{WATER SAFETY PLANNING FOR URBAN WATER UTILITIES Practical Guide for ADB Staff}

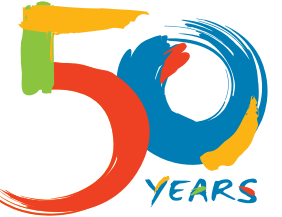


(C) 2017 Asian Development Bank

6 ADB Avenue, Mandaluyong City, 1550 Metro Manila, Philippines

Tel +632632 4444; Fax +6326362444

www.adb.org

Some rights reserved. Published in 2017

ISBN 978-92-9257-789-6 (Print), 978-92-9257-790-2 (e-ISBN)

Publication Stock No. TIM168532-2

DOI: http://dx.doi.org/10.22617/TIM168532-2

The views expressed in this publication are those of the authors and do not necessarily reflect the views and policies of the Asian Development Bank (ADB) or its Board of Governors or the governments they represent.

ADB does not guarantee the accuracy of the data included in this publication and accepts no responsibility for any consequence of their use. The mention of specific companies or products of manufacturers does not imply that they are endorsed or recommended by ADB in preference to others of a similar nature that are not mentioned.

By making any designation of or reference to a particular territory or geographic area, or by using the term "country" in this document, $\mathrm{ADB}$ does not intend to make any judgments as to the legal or other status of any territory or area.

This work is available under the Creative Commons Attribution 3.0 IGO license (CC BY 3.0 IGO)

https://creativecommons.org/licenses/by/3.0/igo/. By using the content of this publication, you agree to be bound by the terms of this license. For attribution, translations, adaptations, and permissions, please read the provisions and terms of use at https://www.adb.org/terms-use\#openaccess

This CC license does not apply to non-ADB copyright materials in this publication. If the material is attributed to another source, please contact the copyright owner or publisher of that source for permission to reproduce it. ADB cannot be held liable for any claims that arise as a result of your use of the material.

Please contact pubsmarketing@adb.org if you have questions or comments with respect to content, or if you wish to obtain copyright permission for your intended use that does not fall within these terms, or for permission to use the ADB logo.

Notes:

In this publication, “\$” refers to US dollars.

Corrigenda to ADB publications may be found at http://www.adb.org/publications/corrigenda 


\section{CONTENTS}

Table and Figures

Abbreviations $\quad$ vi

Introduction 1

Relevance of Water Safety Plans to the Asian Development Bank 1

Relationship between the Water Safety Plan Approach and ADB Policies, Guidelines, and

Documents

Benefits of Water Safety Plans to Water Supply Projects 3

Adoption of Water Safety Plans Globally 4

Purpose of This Handbook 5

Target Users of This Handbook 6

$\begin{array}{ll}\text { Part 1: Overview of Concepts and Principles } & 7\end{array}$

A. World Health Organization Guidelines for Drinking-water Quality 7

B. Water Safety Plans 8

C. Relevance to ADB Loan Processing 8

D. Mainstreaming Water Safety Plans into ADB operations 9

Part 2: Integration of Water Safety Plans into ADB's Project Cycle 10

A. Country Partnership or Regional Cooperation Strategy Stage 11

B. Project Preparation Stage $\quad 12$

B1. Project Concept Note 12

B2. Limits of the Project and Responsibilities

B3. Preliminary Assessment 13

B4. Water Quality Objectives 13

B5. Water Safety Plans 14

C. Project Approval Stage 16

C1. Due Diligence 16

C2. Preliminary Water Safety Plan Activities 16

C3. Project Appraisal 17

D. Project Implementation Stage 18

D1. Role of the Client 18

D2. Design Review 19

D3. Review of Progress during Implementation $\quad 19$

$\begin{array}{ll}\text { D4. Operations } & 20\end{array}$ 
E. Project Completion and Evaluation Stage $\quad 21$

$\begin{array}{ll}\text { F. Checklist } & 21\end{array}$

$\begin{array}{ll}\text { F1. Project Preparation Stage } & 21\end{array}$

F2. Project Technical Assessment Stages $\quad 21$

F3. Project Implementation Stage $\quad 22$

F4. Project Completion and Evaluation Stage $\quad 22$

G. A Step-by-Step Guide to Making Water Safety Plans Happen 22

H. Indicators of Water Safety Plan Implementation and Their Assessment 29

Part 3: Templates $\quad 31$

A. Water Safety Plan Document 31

B. Design and Monitoring Framework for an ADB Project 32

C. Terms of Reference for a Water Safety Plan Expert 33

Part 4: References and Supporting Documents 


\section{TABLES AND FIGURES}

\section{Tables}

1 Water Safety Plan Integration into ADB's Project Cycle 10

2 Step-by-step Water Safety Plan Implementation Guide Summary for ADB Project Officer 23

3 Overview of Water Safety Plan in Project Design and Monitoring Framework 32

4 Tasks and Approximate Inputs for an Early Phase Water Safety Plan 35

5 Credentials and Roles of the Core Water Safety Plan Team 36

\section{Figure}

1 Overview of Water Safety Plan Steps

2 Overview of the Framework for Safe Drinking-water as Set Out in the Guidelines for Drinking-Quality

3 Example of a Water Safety Plan Cover Page and Tables of Contents

4 Gantt Chart Showing How a Water Safety Plan Might Be Phased and the Approximate Effort (Days of Work) Required from Key Stakeholders 


\section{ABBREVIATIONS}

$\begin{array}{lll}\text { ADB } & - & \text { Asian Development Bank } \\ \text { CPS } & - & \text { country partnership strategy } \\ \text { GDWQ } & - & \text { Guidelines for Drinking-water Quality } \\ \text { HACCP } & - & \text { Hazard Analysis and Critical Control Points } \\ \text { KPI } & - & \text { key performance indicators } \\ \text { PAM } & - & \text { project administration manual } \\ \text { PPTA } & - & \text { project preparatory technical assistance } \\ \text { RCS } & - & \text { regional cooperation strategy } \\ \text { TA } & - & \text { technical assistance } \\ \text { TOR } & - & \text { terms of reference } \\ \text { WHO } & - & \text { World Health Organization } \\ \text { WSP } & - & \text { Water Safety Plan }\end{array}$




\section{ACKNOWLEDGMENTS}

This practical guide was initially prepared to provide a step-by-step guide for ADB Staff to include good practice objectives and principles in drinking water quality management in the preparation of ADB's water supply projects. It follows the World Health Organization's Water Safety Plan Manual, and adapts the approach to ADB's operations.

We are most grateful to the World Health Organization, especially to Jennifer de France (technical officer), David Surtherland (technical officer), and Angella Rinehold (consultant) who have generously shared references and materials and spent long hours reviewing the drafts and providing detailed comments.

We thank the ADB team: Alan Baird (senior urban development specialist) for spearheading the production of this guide; Tatiana Gallego-Lizon (director, Southeast Asia Urban Water Division) for presenting the initial recommendations of the draft handbook during the 2016 Global Water Safety Planning Conference in Palawan, Philippines; and the technical peer reviewers consisting of Hubert Jenny (principal infrastructure specialist), Sanjay Joshi (principal urban development specialist), Satoshi Ishii (senior urban development specialist), Neeta Pokhrel (senior urban development specialist), Lu Shen (senior urban development specialist), and Michael White (urban development specialist for water supply and sanitation) for their valuable contributions to the preparation of this guide.

We gratefully acknowledge Dan Deere (consultant) who assisted in the drafting of the guidelines; Ellen Pascua (consultant) who undertook technical editing of the draft; and Pia Reyes (water resources officer), Carmela Fernando Villamar (analyst), and Ginojesu Pascua (consultant) who conducted logistics and administrative activities to finalize this publication.

This Practical Guide also benefitted from the support and encouragement of Vijay Padmanabhan (technical advisor, Urban) and Gil-Hong Kim (senior director, Sector Advisory Services Division, concurrently chief sector officer). 



\section{INTRODUCTION}

\section{RELEVANCE OF WATER SAFETY PLANS TO THE ASIAN DEVELOPMENT BANK}

A Water Safety Plan (WSP) is defined by the World Health Organization (WHO) as "a comprehensive risk assessment and risk management approach that encompasses all steps in water supply from catchment to consumer" to ensure safe drinking-water. It is described in the WHO's Guidelines for Drinking-water Quality (GDWQ) as the "most effective means of consistently ensuring the safety of a drinking-water supply (footnote 1)." It is implemented as a series of steps that are revisited periodically, as illustrated in Figure 1.

The Asian Development Bank (ADB) has a strong interest in ensuring that prolonged and full benefit is realized from its loans to maximize their value. In addition, good practice in any urban water project involves having a system in place to ensure that the water supply remains at the desired quality beyond the initial construction of the capital infrastructure. An important management system approach to help achieve this longer-term goal is the WSP.

WSP is a valuable tool to assist water suppliers and other stakeholders to systematically identify and prioritize system needs, from low-cost operational and management solutions to more capitalintensive infrastructure improvements. Furthermore, where infrastructure improvements are necessary for the provision of safe drinking-water, WSPs serve to maximize the effectiveness and sustainability of those improvements by ensuring that appropriate operations and management systems are in place to support the water supply system over the long term.

ADB has a commitment to playing its part in the long-term goal of providing safe drinking-water throughout the Asia and Pacific region. Current good practice in drinking-water supply projects includes due consideration being given to the WSP preventive risk management approach.

ADB's urban water supply projects would not be expected to pose health risks to the public, particularly to drinking-water customers. WSPs help guide the management of direct public health risks as well as indirect risks (e.g., reputational risks or liabilities) to ADB and client governments.

In the short term, ADB does not wish to provide financing for drinking-water supply projects that inadvertently contribute to increased or unacceptable disease burdens. One of the more widely publicized examples of large-scale water supply interventions that didn't adequately cover drinkingwater safety was the experience in Bangladesh where a proportion of water supply wells contained 


\section{Figure 1: Overview of Water Safety Plan Steps}

\section{How to develop and implement a Water Safety Plan}

A step-by-step approach using II learning modules

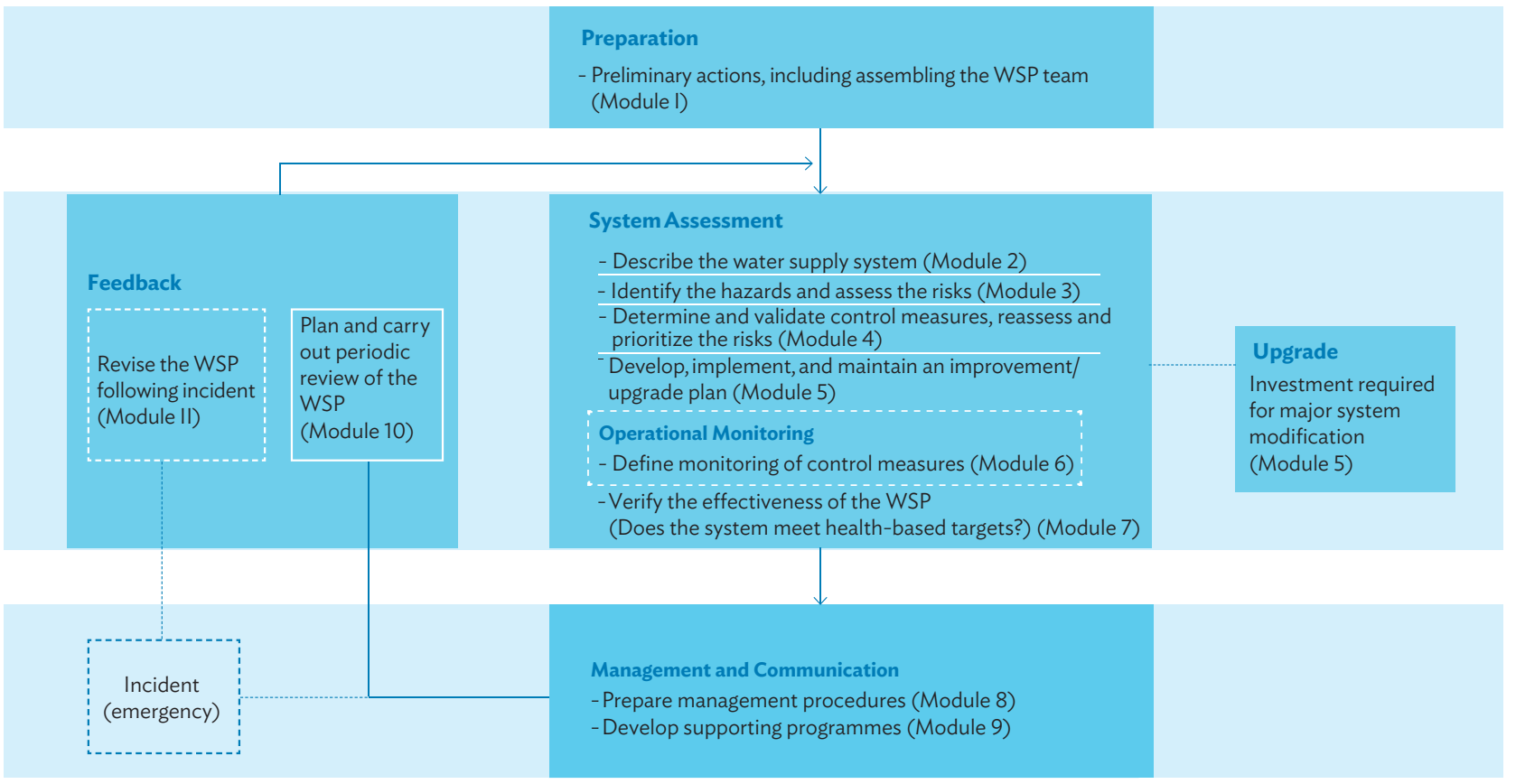

Source: Bartram, J. et al. 2009. Water Safety Plan Manual: Step-by-step risk management for drinking-water suppliers. Geneva, Switzerland: WHO.

elevated arsenic. ${ }^{2}$ ADB recognizes that WSPs include an accepted approach to systematically assessing risks to drinking-water safety and ensuring that significant risks are mitigated to acceptable levels.

The implementation of the WSP is not mandatory for ADB loans. Rather, the WSP represents good practices that $A D B$ may consider and promote in providing loans related to urban water infrastructure. On that basis, this Handbook is guiding and is not intended to be prescriptive at all as to how and to what extent WSPs should be implemented as part of ADB projects.

2 Smith, A., Lingas, E., and Rahman, M. 2000. Contamination of drinking-water by arsenic in Bangladesh: a public health emergency Bulletin of the World Health Organization. 78 (9). 


\section{RELATIONSHIP BETWEEN THE WATER SAFETY PLAN APPROACH AND ADB POLICIES, GUIDELINES, AND DOCUMENTS}

The WSP approach is consistent with key components of some ADB policies, guidelines, and documents that are relevant to the water sector and health promotion:

- At the highest level, ADB's Strategy 2020: The Long-Term Strategic Framework of the Asian Development Bank 2008-2020 sets out that investing in water supply infrastructure is intended to contribute to public health, and is one of ADB's core areas of operations. ADB considers infrastructure projects related to water management a key contribution to improvements in health and gender equity. WSPs provide a tool to ensure that drinking-water supply projects are managed in the long term to deliver safe water and, thereby, achieve the public health contribution envisaged for the water supply projects described in Strategy 2020.

- In relation to water specifically, ADB's Water for All: The Water Policy of the Asian Development Bank 2001 highlights that providing increased access to safe water will translate to less illness and higher productivity, and notes the synergy between water supply and ADB's broader poverty reduction strategy. In addition, ADB's Water Operational Plan 2011-2020 states that lack of access to safe water is a barrier to improving health and widening access to education. ADB's investment in water supply infrastructure is intended to contribute to gender equity and population health outputs. Consistent with these goals, WSPs provide a tool to systematically assess drinking-water safety risks from water supply and to put in place ongoing management approaches to ensure the mitigation of those risks.

- In relation to health, ADB's Operational Plan for Health 2015-2020 notes that investments in water supply are indirect but important contributions to health. The document promotes the need to improve collaboration between the health and infrastructure sectors. Consistent with these goals, WSPs explicitly set out the need to assemble a team of water and health sector professionals to develop, maintain, and review and revise the WSP to support the provision of safe drinking-water.

\section{BENEFITS OF WATER SAFETY PLANS TO WATER SUPPLY PROJECTS}

The historical approach to water safety management, relying on "end of pipe" testing of supplied drinking-water and comparing those results with concentration targets, was quite effective but was partially flawed in that it did not prevent waterborne disease outbreaks but only detected contamination belatedly, i.e., after it had occurred and customers had been exposed. The initial purpose of WSPs was, therefore, to shift the focus away from the reliance on water testing to the operational monitoring and management of the water supply system itself. The traditional "end of pipe" testing is still required but has been relegated to the secondary function of verifying the effectiveness of the WSP. The objective of promoting WSPs is to broaden the emphasis of water quality management to include operations and management of water supplies. This broader approach is preferable to the narrower focus on water quality compliance monitoring, which was often the predominant consideration of water suppliers, surveillance agencies, and regulators prior to the implementation of WSP guidelines. 
WSPs have proven to be an important tool for developing a new corporate culture in drinking-water utilities, moving from rigid, singular risk aversion to dynamic, comprehensive risk assessment and management.

The benefits of WSPs are as follows:

- Traditional guidelines entail water quality monitoring of product.

$>$ This finds contamination after exposure.

$>$ The monitoring is often infrequent (weekly, monthly, annually).

- WSPs refocus testing on processes.

$>$ The process should detect failures early and correct those failures before exposure to contamination.

$>$ The process monitoring is often frequent (ideally continuous).

- WSPs are risk-based.

$>$ WSPs involve systematically identifying failure modes and risks that can lead to adverse health outcomes.

$>$ WSPs guide the implementation of both engineering and management system controls to prevent failures.

- WSPs are locally tailored to respond to factors such as

$>$ estimated contamination levels and risks for a specific system;

$>$ expectations of investors and clients;

$>$ willingness or ability to recover costs from the community; and

$>$ expectations of water quality standards including health and, possibly, acceptability aspects.

- In general WSPs are expected to lead to significantly improved health and cost-benefit outcomes. As WSPs are rolled out, it is more apparent that they offer more benefits, in terms of

$>$ improving regulation, operation, and maintenance of water supply systems, which saves money and improves the targeting of resources;

$>$ reducing nonrevenue water, as there is a focus on leakage reduction, constant pressure maintenance in the system, and communication with customers;

$>$ providing information on asset condition and management, and associated current and future investment requirements; and

$>$ assessing the impact of development on water supply systems and their catchments.

\section{ADOPTION OF WATER SAFETY PLANS GLOBALLY}

The management of water safety through WSPs (or equivalent) is increasingly being formalized globally as an obligation or strongly promoted good practice for urban water supplies. In a recent WSP implementation progress report, it was noted that "92 countries, representing every region of the world, have implemented WSPs or equivalent risk assessment and risk management approaches." ${ }^{3}$ Examples include the following:

- WSPs have been piloted and are being rolled out across Malaysia following the completion of a guiding handbook for the country (Water safety plan handbook for rural water supply systems, Ministry of Health Malaysia, 2011).

3 WHO and International Water Association. 2016. Global Water Safety Plan Status Report. http://www.wsportal.org/ 
- WSPs have been implemented in Japan with the Ministry of Health, Labour and Welfare having issued guidelines for WSP development and recommending the application of WSPs to drinkingwater quality management (Ministry of Health, Labour and Welfare Guidelines for the development of a water safety plan, May 2008).

- The Australian states have required documents named as risk management plans or drinking water quality management plans to be implemented by water suppliers, and these are subject to regulatory audit by licensing authorities [Public Health Act 1997 (Tasmania), Safe Drinking Water Act 2003 (Victoria), Water Industry Competition Act 2006 (New South Wales), Water Supply (Safety and Reliability) Act 2008 (Queensland), Safe Drinking Water Act 2011 (South Australia)].

- Outside the Asia and Pacific region, drinking water safety plans are recommended as a good practice in various jurisdictions, including the United Kingdom (Drinking Water Inspectorate, A Brief Guide to Drinking Water Safety Plans, 2005); Ireland (Environmental Protection Agency, Drinking Water Advice Note No. 8: Developing Drinking Water Safety Plans, 2011); and Alberta, Canada (Government of Alberta, A Guidance Framework For the Production of Drinking Water Safety Plans, 2016).

\section{PURPOSE OF THIS HANDBOOK}

This ADB Staff Handbook guides the efficient integration of the WSP approach into ADB's urban water operations. It has been produced primarily to facilitate compliance of ADB's urban water projects with global good practice objectives, principles, and practices to manage health risks to drinkingwater customers. It is intended to guide the mainstreaming of these good WSP practices into ADB operations.

ADB has a major influence on drinking-water supply within its area of operations. This influence can arise both from direct loans for drinking-water supply infrastructure and indirectly from loans that result in the modification of infrastructure or environments. Examples of the types of ADB projects that directly or indirectly influence the quality of drinking-water supplied to communities include the following:

- Direct influence

$>$ Drinking-water infrastructure projects, such as water reticulation networks or water treatment plants

$>$ Water resources infrastructure projects, of which one of the intended beneficial uses is subsequent drinking-water supply

- Indirect influence

$>$ Projects that draw water from drinking-water sources (dams, weirs, reservoirs, and rivers), or add water to drinking-water sources, and as a result change the flow of rivers or the level of water in water storages (such as agricultural use and irrigation)

$>$ Projects that either pollute or clean up drinking-water sources, such as environmental remediation projects or infrastructure investments relating to mining or industry

$>$ Projects that provide basic infrastructure that in turn facilitate improvements in water supply and quality, such as power infrastructure investments

It is essential that ADB projects that directly influence drinking-water safety and have a drinking-water supply component consider the relevant components of the WSP. This Handbook is targeted to such projects. Note that many of these practices are inherent in good project design and loan processing 
and need not create significant extra work beyond what is typically required as part of properly implemented $\mathrm{ADB}$ processing activities.

Projects that indirectly influence drinking-water supply, safety, and quality would be covered under ADB's "Safeguards" requirements. ${ }^{4}$ This Handbook is not targeted to such projects, but consideration of the broader water resources management context is considered good practice in such scenarios.

\section{TARGET USERS OF THIS HANDBOOK}

The intended users of this Handbook are ADB project officers involved in processing urban water projects that incorporate WSPs and in related technical assistance (TA) supporting project delivery. The attention of project officers is primarily drawn to this introductory section and Part 1 of the Handbook. TA personnel are the principal target audience of Parts 2-4 of the Handbook.

For project preparation, the Handbook provides guidelines and templates, including terms of reference (TOR) for early technical assessments and project preparatory technical assistance (PPTA) stages.

During project implementation, this Handbook serves as an instrument to monitor compliance with WSP implementation. It also gives criteria for evaluation of WSP development and functioning in the project context.

4 See Appendix 1 (specifically para. 33, p 36 and paras. 42-44, pp. 38-39) of ADB. 2009. Safeguard Policy Statement. Manila, Philippines: ADB. https://www.adb.org/sites/default/files/institutional-document/32056/safeguard-policy-statement-june2009.pdf 


\section{PART 1}

\section{OVERVIEW OF CONCEPTS AND PRINCIPLES}

\section{A. WORLD HEALTH ORGANIZATION GUIDELINES FOR DRINKING-WATER QUALITY}

The WHO structures the Guidelines for Drinking-water Quality (GDWQ) as a water safety framework (Figure 2). The framework consists of three component parts: health-based targets, WSP, and surveillance. Together these components are intended to achieve the desired public health outcome. The framework is applicable to systems of all types from large complex piped systems to communitymanaged sources. The WSP component is the most relevant to ADB activity since the WSP directly relates to infrastructure and operations. WSPs can be guided by health-based targets (as generally incorporated into national drinking-water standards or regulations) and overseen by independent surveillance to ensure that WSPs are developed appropriately and implemented effectively and that health-based targets are being met.

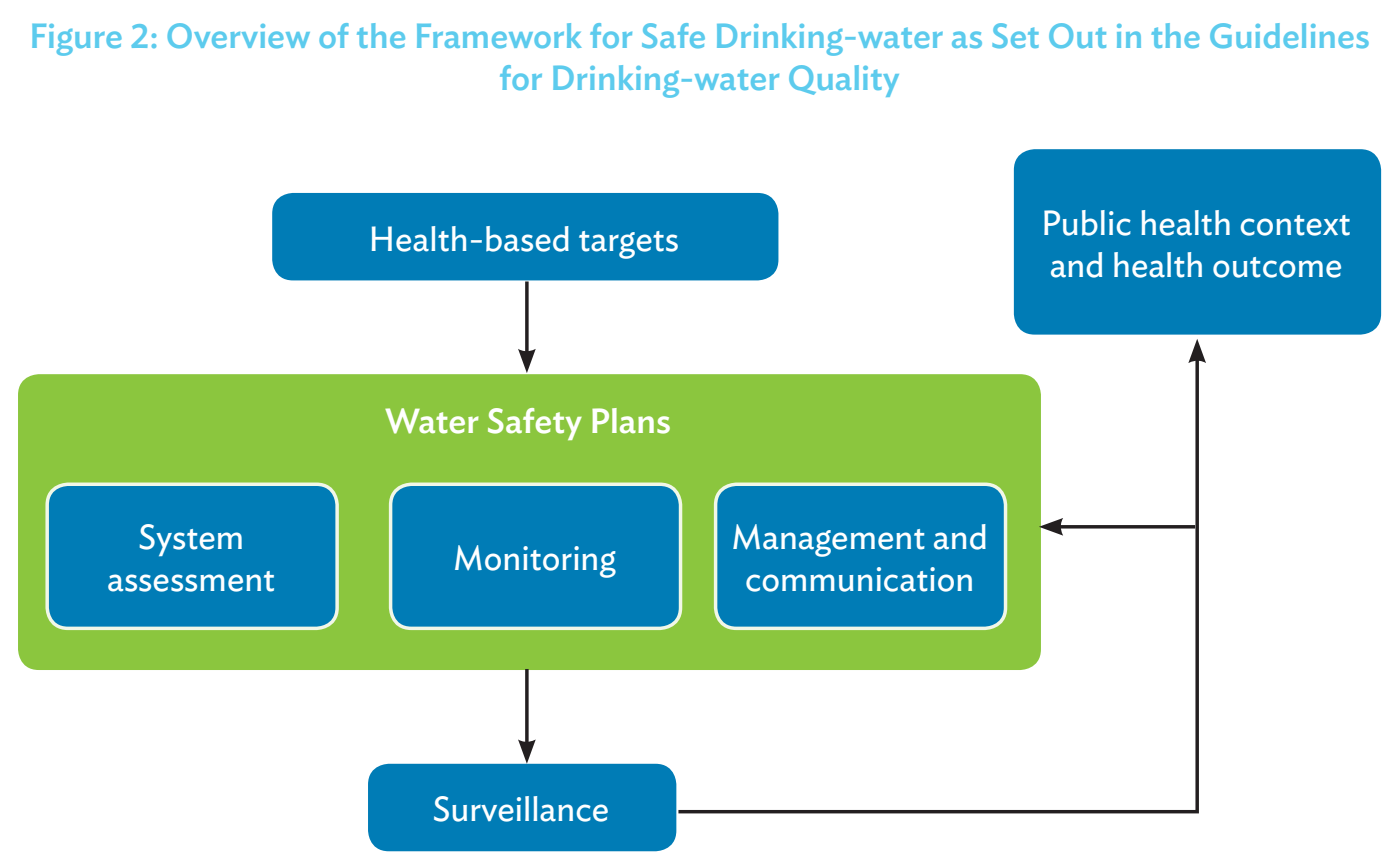

Source: Source: Based on WHO. 2011. Chapter 1: Introduction. In Guidelines for Drinking-water Quality. 4th ed. Geneva, Switzerland: WHO 


\section{B. WATER SAFETY PLANS}

The WHO structures the WSP as a series of steps (Figure 1). Chapter 4 of the GDWQ ${ }^{5}$ describes WSPs in more detail, and the WSP Manual provides step-by-step guidance for developing and implementing WSPs. ${ }^{6}$ The WSP is an example of a preventive drinking-water quality management system approach for reliably achieving objectives relating to water quality and public health. The WSP has direct management system parallels that will be familiar to many practitioners, including

- quality management (ISO 9000);

- food safety management (food safety plans, Hazard Analysis and Critical Control Points (HACCP) plans, ISO 22000);

- $\quad$ asset management (ISO 55000);

- risk management (ISO 31000); and

- environmental management (ISO 14000).

Since the beginning of the 2000s, jurisdictions globally have been increasingly adopting formal WSP approaches to drinking-water safety and quality management. The WSP approach is now the accepted global norm in good drinking-water quality management.

Note that the term "Water Safety Plan" is not used in all jurisdictions, and that other terms used include the following and their variations:

- Risk Management Plan

- Public Health Risk Management Plan

- Quality Assurance Program

- Drinking Water Management Plan

- Drinking Water Quality Management Plan

- Drinking Water Safety Plan

- HACCP Plan

In this Handbook, the term "Water Safety Plan" (WSP) will be used to refer to all of those approaches.

\section{RELEVANCE TO ADB LOAN PROCESSING}

Some of the WSP principles are relevant to design and construction as well as to initial operation of water infrastructure. If a system is designed poorly, it will be very difficult to provide safe water in the long term. Therefore, where necessary, relevant aspects of the WSP approach may be captured within ADB processing activities to promote their long-term adoption by the water supplier.

WHO. 2011. Chapter 4: Water safety plans. In Guidelines for Drinking-water Quality. 4th ed. Geneva.

6 Bartram J. et al. 2009. Water Safety Plan Manual, Step-by-step risk management for drinking-water suppliers. Geneva, Switzerland: WHO. 
WSPs continue to be relevant beyond the period of ADB financing and involvement. A WSP is intended to exist as an operational document and a living drinking-water quality risk management system that is owned, maintained, and implemented by drinking-water suppliers. ${ }^{7}$ WSPs can also assist in guiding design, construction, and education. ADB works in partnership with stakeholders and is not directly responsible for operating water supply infrastructure. Some discretion is required when applying WSP principles in ADB projects to ensure that aspects relevant to ADB's role are appropriately allocated.

\section{MAINSTREAMING WATER SAFETY PLANS INTO ADB OPERATIONS}

It is important to adopt an efficient approach in meeting the principles and intent of the WSP. To a large extent, ADB projects already inherently incorporate the WSP principles by considering the client government's local standards and existing good practices. Thus, it is most efficient to avoid replication of activities by starting with a gap analysis that maps and compares the existing project processes with the WSP principles. In addition to avoiding replication of activities, the gap analysis highlights the risk of undesirable impacts on drinking-water customers and the reputational or liability risks to ADB or client governments.

\footnotetext{
7 The supplier may be a water utility, cooperative, community water supply entity, or local caretaker.
} 


\section{PART 2}

\section{INTEGRATION OF WATER SAFETY PLANS INTO ADB'S PROJECT CYCLE}

This Handbook is structured around ADB's project cycle and illustrates how the WSPs can be mainstreamed into each of those steps as summarized in Table 1. The section begins by discussing the project cycle and then provides a step-by-step guide that can be used as a concise checklist to guide implementation.

Table 1: Water Safety Plan Integration into ADB's Project Cycle

\begin{tabular}{|c|c|c|c|c|}
\hline $\begin{array}{l}\text { ADB Project } \\
\text { Cycle }^{a}\end{array}$ & ADB Activity & WSP Activity & $\begin{array}{c}\text { Example } \\
\text { Deliverable }\end{array}$ & $\begin{array}{c}\text { Possible } \\
\text { Responsibility }\end{array}$ \\
\hline $\begin{array}{l}\text { Country } \\
\text { partnership } \\
\text { or regional } \\
\text { cooperation } \\
\text { strategy }\end{array}$ & $\begin{array}{l}\text { Water supply } \\
\text { sector } \\
\text { assessment }\end{array}$ & $\begin{array}{l}\text { Conduct a country or regional scale } \\
\text { gap analysis of the counterpart's } \\
\text { regional or national drinking-water } \\
\text { safety and quality obligations, } \\
\text { and look for evidence of WSP (or } \\
\text { equivalent) practices. } \\
\text { Critically review gaps and consider } \\
\text { whether ADB would expect any to } \\
\text { be filled. }\end{array}$ & $\begin{array}{l}\text { Gap analysis that } \\
\text { critically reviews } \\
\text { inconsistencies } \\
\text { between WSP good } \\
\text { practice and country } \\
\text { or regional drinking- } \\
\text { water safety and } \\
\text { quality obligations }\end{array}$ & $\begin{array}{l}\text { Country } \\
\text { Coordinator }\end{array}$ \\
\hline $\begin{array}{l}\text { Project } \\
\text { preparation }\end{array}$ & $\begin{array}{l}\text { Feasibility study } \\
\text { and technical } \\
\text { assessment }\end{array}$ & $\begin{array}{l}\text { Conduct a project scale gap analysis } \\
\text { of the counterpart's drinking-water } \\
\text { safety and quality obligations } \\
\text { against the objectives, principles, } \\
\text { and practices relating to WSPs. } \\
\text { Critically review gaps and consider } \\
\text { whether ADB would expect any to } \\
\text { be filled. }\end{array}$ & $\begin{array}{l}\text { Gap analysis that } \\
\text { critically reviews } \\
\text { inconsistencies } \\
\text { between WSPs and } \\
\text { the counterpart's } \\
\text { drinking-water } \\
\text { safety and quality } \\
\text { obligations }\end{array}$ & $\begin{array}{l}\text { Project Officer } \\
\text { May be } \\
\text { delegated to } \\
\text { Water Quality } \\
\text { Specialist }\end{array}$ \\
\hline Project approval & $\begin{array}{l}\text { Due diligence } \\
\text { technical } \\
\text { assessment }\end{array}$ & $\begin{array}{l}\text { Form a core WSP team to describe } \\
\text { the proposed system, carry out a } \\
\text { drinking-water safety and quality } \\
\text { risk assessment, design control } \\
\text { measures (risk mitigation) } \\
\text { and develop an operational } \\
\text { monitoring plan. } \\
\text { Assemble the above deliverables } \\
\text { into a preliminary partial WSP that } \\
\text { covers the core components of a } \\
\text { WSP. } \\
\text { Develop performance indicators } \\
\text { for full implementation of the WSP } \\
\text { by the proposed operating water } \\
\text { supplier and surveillance agency. }\end{array}$ & $\begin{array}{l}\text { Preliminary partial } \\
\text { WSP }\end{array}$ & $\begin{array}{l}\text { Technical } \\
\text { Assessment } \\
\text { Team Leader } \\
\text { May be } \\
\text { delegated to } \\
\text { Water Quality } \\
\text { Specialist }\end{array}$ \\
\hline
\end{tabular}


Table 1 continued

\begin{tabular}{|c|c|c|c|c|}
\hline $\begin{array}{l}\text { ADB Project } \\
\text { Cycle }^{a}\end{array}$ & ADB Activity & WSP Activity & $\begin{array}{l}\text { Example } \\
\text { Deliverable }\end{array}$ & $\begin{array}{l}\text { Possible } \\
\text { Responsibility }\end{array}$ \\
\hline $\begin{array}{l}\text { Project } \\
\text { implementation }\end{array}$ & $\begin{array}{l}\text { Design review } \\
\text { Implementation } \\
\text { review } \\
\text { Operation }\end{array}$ & $\begin{array}{l}\text { Assess and report on progress on } \\
\text { implementation of the WSP. }\end{array}$ & $\begin{array}{l}\text { WSP } \\
\text { implementation } \\
\text { review report }\end{array}$ & $\begin{array}{l}\text { Project Officer } \\
\text { May be } \\
\text { delegated to } \\
\text { Water Quality } \\
\text { Specialist }\end{array}$ \\
\hline $\begin{array}{l}\text { Project } \\
\text { completion and } \\
\text { evaluation }\end{array}$ & $\begin{array}{l}\text { Project } \\
\text { monitoring and } \\
\text { evaluation }\end{array}$ & $\begin{array}{l}\text { Assess and report on progress on } \\
\text { implementation of the WSP. }\end{array}$ & WSP audit report & $\begin{array}{l}\text { Project Officer } \\
\text { May be } \\
\text { delegated to } \\
\text { Water Quality } \\
\text { Specialist }\end{array}$ \\
\hline
\end{tabular}

$\mathrm{ADB}=$ Asian Development Bank, WSP = Water Safety Plan.

${ }^{a}$ ADB. Project Cycle. https://www.adb.org/projects/cycle

\section{A. COUNTRY PARTNERSHIP OR REGIONAL COOPERATION STRATEGY STAGE}

When completing or updating a country partnership strategy (CPS) or regional cooperation strategy (RCS) that includes a water supply sector assessment component, the assessment can explicitly consider the sector readiness for WSP implementation. The client government's applicable water quality guidelines or standards can be compared to the GDWQ, the global good practice benchmark, in particular Chapter 4 which covers WSPs.

If the client government's drinking-water quality obligations are consistent with the WSP principles (globally accepted good practices), then no significant gaps will be identified. However, in some cases, significant gaps may exist. This potentially presents a risk to the community, government, and ADB, especially when loans are provided to projects that deliver drinking-water that may be considered unsafe or unacceptable.

In order to mitigate this risk for countries in which $A D B$ is active in the drinking-water supply sector, it is recommended that ADB compares the obligations that would ordinarily be applied to ADB loans (typically the local obligations applying within the government's jurisdiction) to the global normative drinking-water guidelines (GDWQ). ${ }^{8}$ Chapter 4 of the GDWQ covers WSPs relating to drinking-water quality risk assessment and preventive risk management.

One way to conduct a gap analysis is to prepare a simple checklist or table of the key WSP principles along with a summary of how comprehensively each is addressed by the country and how well the ADB loan processing team will assess their implementation.

8 WHO. 2011. Guidelines for Drinking-water Quality. 4th ed. Geneva, Switzerland:WHO. http://www.who.int/water_sanitation_ health/publications/dwq-guidelines-4/en/ 
At the CPS stage it is not expected that a WSP (or equivalent) will be developed. However, the water supply sector assessment may identify the WSP (or equivalent) approach that is to be applied to ADB projects in the country to comply with local, regional, or national standards or guidelines (as applicable).

The review may consider the local formal requirements as well as the guidelines that are often available, such as locally developed WSP guidelines and case studies.

If no WSP (or equivalent) approach is required in the relevant country jurisdictions, then a decision needs to be made as to whether to adopt the GDWQ or some other WSP approach, and if indeed any WSP approach is to be adopted at all.

\section{B. PROJECT PREPARATION STAGE}

\section{B1. Project Concept Note}

It would be too early to develop a WSP at the initial project concept stage. However, a project concept paper could highlight the WSP as a tool to support the higher-level goals of the project, which, in most cases, will be to improve health through the provision of safe drinking-water.

During the project concept stage, the ADB team could review the potential to incorporate WSPs, including their implications in setting project boundaries. The WSP approach can be applicable to all urban and rural water supply systems regardless of their level of complexity and governance. The ADB team could provide information to the government and utility counterparts to promote the incorporation of WSPs as a strategy to consistently ensure the safety and acceptability of a drinkingwater supply.

\section{B2. Limits of the Project and Responsibilities}

This Handbook is intended to apply primarily to loans that are intended to directly and intentionally invest in urban water supply. It is largely aimed at the physical, operational, and institutional scope of work of ADB projects. However, it is acknowledged that in practice, components of the client's assets and systems that are outside the scope of the ADB project may need to be included in the scope of a WSP in order for the component supported by ADB to function appropriately and for the broader goals of the project to be attained. Under such circumstances ADB may need to promote broader implementation of the WSP including by other agencies and for other infrastructure that influences the scope of the ADB loan. ADB would not have direct obligations thereto under the implementation of the WSP, but it would have an advocacy role. Therefore, an up-front activity within ADB projects involving WSP components is to agree on boundaries and limits of WSP activity and responsibility and to note where responsibilities lie beyond ADB activity. In some cases ADB projects fund a part only of water supplies, e.g., treatment plants, dams, or networks or parts of networks. In such cases this Handbook needs to be interpreted appropriately, and it may only partially apply, albeit it promotes the implementation of WSPs to the whole. 


\section{B3. Preliminary Assessment}

As noted under the discussion of the CPS and RCS, ADB projects that include a significant drinkingwater supply component must ensure compliance with the government's local, regional, or national standards or guidelines (as applicable). However, often the CPS or RCS will not consider local variations in drinking-water quality obligations, and these can be quite significant.

There is no single or set way to implement WSP principles. What is important is that the approach fits in with the way a water utility (or equivalent) is organized and operates, relates to the socioeconomic reality of the country where it is deployed, and is relevant to defined roles and responsibilities. It would be useful, for example, to have economic or financial inputs from the technical assessment team members feed into the WSP, and for the WSP to inform the economic and financial analysis. It is recognized, however, that in practice the alignment of these various analyses cannot be assured.

As part of the feasibility study and other technical assessment, review, and appraisal processes, one or more of the WSP steps may be addressed inherently in part or even in full. Examining the WSP steps against tasks and deliverables already forming part of the project not only can help identify gaps but can also serve to avoid replication of effort and find synergies and efficiencies.

There may be blatant gaps, e.g., a full unplanned WSP step, or partial gaps such as an action that will only partially address the intent of a particular WSP component.

The checklist for the design stage (managed by the design team) might be different from the implementation stage (managed by the water supplier or equivalent entity). This is discussed in more detail below in relation to assessment (Section C3).

\section{B4. Water Quality Objectives}

\section{B4.1 Due Diligence}

As part of technical due diligence, it is important to consider the quality of drinking-water that will be delivered to customers. The quality needs to be considered from the health-related perspective at the very least. Ideally, quality would also be considered from an acceptability perspective (e.g., appearance, taste, and smell; or cultural factors). A table could be created to set out the water quality objectives (WQO) for the ADB project and to highlight any possible gaps. It is possible that a similar table is prepared at the country level as part of the CPS; if so, that previously developed table can form the start point for the project-level assessment. Liaison with $\mathrm{WHO}$ and the national ministries responsible for water and health is important in this context in order to understand these objectives as well as future plans that are currently in progress and that may become significant during the loan or operational period of the infrastructure supported by the ADB loan. Seeking and identifying suitable WHO contacts can be achieved by contacting the local country office or regional office. The up-to-date contact details for each of the regional offices and country offices can be found on the WHO website (at http://www.who.int/about/en/).

\section{B4.2 Health-related Aspects}

An early step in ADB urban water supply projects that include a design-build component could include gaining agreement on the health-related WQO for the project. The WQO would typically present at least two values:

- WQO values proposed by the counterpart (typically the national or regional standards in the counterpart's jurisdiction), and

- GDWQ values. 
If there is a water treatment component to the project, then it is important to consider the project's pathogen reduction requirements early to avoid potential cost overruns and inadequate water safety. The pathogen reduction requirements to achieve the GDWQ health-based targets for the project are increasingly providing inputs to process design.

In some cases, other values, such as alternative in-country WQO or ADB lender WQO, may need to be indicated. Any gaps could be highlighted and a decision made and formally recorded in relation to their implications. A decision could be made by the counterpart in liaison with the team leader as to which gaps can or cannot be accepted and why, and the technical peer review process could check that decision.

Ideally, this analysis would be conducted jurisdiction-by-jurisdiction and a decision would be made for each jurisdiction as to what obligations, if any, would be undertaken in addition to the local counterpart's obligations. If no such jurisdiction-based analysis has been conducted, that analysis will need to be project-by-project. In both cases the analysis would ideally be undertaken in liaison with the local counterpart's regulator for water and health and potentially with WHO.

\section{B4.3 Acceptability-related Aspects}

Urban water is to be used for drinking in situations where there may be less safe alternative sources of water available to the community. It is important that safe water is acceptable to the community to ensure its use in preference to the unsafe alternative. In addition, if urban water is intended to be charged to the community, higher revenues and improved community satisfaction can be assured by providing acceptable water. In such scenarios, acceptability considerations could be included in the WQO.

\section{B4.4 Unwritten Norms}

In some circumstances, aspects of the local standards are known to be outdated and improved standards are applied to fill shortfall. It is necessary to review similar new drinking-water supply projects in the jurisdiction, establish what standards were applied as the norm, and seek to match those standards.

\section{B4.5 Special Circumstances}

There may be special circumstances that require some very specific WQO to be developed for some projects. For instance, if the local standards, or even the GDWQ, do not cover an industrial pollutant present in the water source, it would be prudent to set standards for that pollutant based on a toxicological assessment as part of the WQO for a drinking-water supply scheme intending to use that source. As another example, the water may be unusually warm and subject to the growth of Legionella and amoebas, requiring additional treatment and management that may influence the WQO.

\section{B5. Water Safety Plans}

The applicable WSP components that need to be completed as part of delivering the project could be established and documented for development during the project approval stage. Note that in many cases the WSP steps introduced below will be undertaken during subsequent stages of the project beyond the project preparation phase. Nonetheless, at the project preparation stage it is important to be cognizant of the importance of all the WSP steps, and to either begin those tasks or at least set up the processes required to ensure their completion during subsequent project phases. For instance, a preliminary and partial WSP at the project preparation stage will be revisited, reviewed, and expanded during the project approval and subsequent stages, as applicable. 
Any project that involves modifying or creating physical infrastructure could complete the following WSP steps within the project scope boundaries:

- Form a core WSP team incorporating suitable operational and technical knowledge and expertise. ADB staff could identify the core WSP team members from within the water supplier (if applicable) and external counterparts that would have a potential role in regulation and monitoring. Such a team would comprise individuals who are already involved in the project preparation, such as ADB staff and counterpart agencies (such as the relevant health authority) and water suppliers. The WSP expert could assist in identifying the right stakeholders to be part of the core WSP team. In practice the WSP team would largely consist of the existing project team plus perhaps one additional expert input, if required, and support from the local water supplier and health authority. The WSP team is not a full-time role but a periodic review through participating in workshops and reviewing and providing input to documents.

- Consider the broader stakeholder groups that are to be invited by the core WSP team to provide input to the WSP. This broader stakeholder group may include government agencies, private entities, or community groups that are involved in water resources management. This involvement may include groups or entities responsible for influencing water quality through the discharge of effluent or managing land in the catchment, as well as groups involved in water resources and catchment protection.

- Describe the water supply system, its operation, and its implications for drinking-water quality and health. An overview of the proposed infrastructure would be delineated, including maps, process flow diagrams, and process descriptions of the water supply infrastructure.

- Identify hazards and hazardous events, identify and validate existing control measures, conduct a drinking-water quality risk assessment, and identify additional control measures needed to manage significant drinking-water quality risks. A table that summarizes risks to drinking-water safety and quality would be prepared, as well as the process controls required to mitigate those risks.

- Validate that collectively the new control measures to be implemented will reduce drinking-water quality risks to acceptable levels.

- Set target criteria for important control measures (including critical limits).

- Develop operating procedures for important control measures. These procedures would describe the routine operational monitoring processes (monitoring method, frequency, responsibility, and location) and note the corrections and corrective actions required to respond to deviations from target criteria (and critical limits if applicable).

- Share the above in a form amenable to being incorporated into a WSP in the future by a potential drinking-water supplier and advocate its ongoing implementation beyond the life of the loan.

Larger, more comprehensive projects may include additional steps. For instance, for projects that develop or modify the majority of a water supply system, it may be appropriate to develop a full WSP from catchment to customer.

To avoid the WSP falling into disuse once ADB moves on, it is necessary to commit to significant training and advocacy effort with the water supplier. That advocacy can be undertaken in partnership with WHO and other entities working on WSPs, including government stakeholders. In addition, a suitable design and monitoring framework could be considered to enable review of the WSP and its implementation (see Section C3 for further details). 


\section{PROJECT APPROVAL STAGE}

\section{C1. Due Diligence}

As part of technical due diligence, it is important that major risks to drinking-water safety and quality are not missed from the project technical assessment. Missing such risks could result in cost overruns or revenue shortfalls as problems eventuate. To minimize such risks to the project, foreseeable risks to drinking-water safety and quality could be highlighted and the means (and costs) of risk mitigation factored into the design of the loan facility.

Consistent with this good due diligence practice, the WSP framework begins with a system description and risk assessment. Therefore, the first part of a preliminary WSP would ideally be completed as part of the project technical assessment.

\section{C2. Preliminary Water Safety Plan Activities}

At the technical assessment stage, a core WSP team could be established to carry out the system assessment; identify hazards and risks; and check the veracity of the WQO (and, where established, pathogen reduction requirements) and of the designed control measures (risk mitigation) and operational monitoring plans.

A specialist with experience in water safety and quality management, including the preparation of WSPs, could form part of the technical assessment team to set out the preparation plans, provide guidance, and review progress. Partner agencies (such as health authorities or WHO) that are also working on incountry WSPs may provide their expertise or make their trainers available to support the teams.

If it is decided that the relevant WSP components need to be included within the design-build phase of the project, then they need to be included either within the project preparatory technical assistance (PPTA) phase (for projects that include a PPTA) or as conditions of the loan agreement where the loan is provided to a project design facility funding or to fund construction based on a design submitted by a counterpart.

The task is less onerous than it may seem at first. For instance, only the core WSP components need to be adopted as part of ADB projects. Furthermore, in most cases, some or even all of the relevant WSP components will be addressed as part of the existing obligations associated with the project since most are inherent in good water engineering design-build projects.

Note that the technical assistant appointed to complete a design or design-build phase cannot be accountable for developing the full operational WSP beyond those components noted in the TOR example. However, to help support sustainable implementation of WSP components within ADB projects, ADB could advocate that the service provider develop a full WSP and utilize the full WSP approach in their longer-term operations.

The documentation and intellectual property relating to the WSP from the technical assessment phase would be designed so that it can be wholly handed over to the service provider and directly incorporated into the service provider's WSP following completion of that phase. However, ADB cannot be held accountable if the service provider chooses to accept the infrastructure without adopting a WSP approach since the accountability for long-term implementation of a WSP rests with the service provider. A key success factor for supplier uptake in the long term will be the supplier's 
investment in or ownership of the preliminary WSP. To the extent practicable and feasible, ADB would approach the preliminary WSP as a supplier-owned or supplier-led process from the start with ADB guidance and support, rather than an ADB-led process followed by handover.

The profile of the personnel is critical. During the assessment phase, the personnel would have adequate experience to identify the hazards to safe water abstraction, treatment, and distribution; or they would have personal or institutional networks to facilitate access to the required expertise. The personnel will need to help identify the cost implications of incorporating the WSP approach during project implementation.

Personnel selected to carry out the technical assessment, including the feasibility study, safeguards assessment, and poverty and social assessment, would be able to demonstrate either (i) an experience in applying and working with WSPs or risk-based approaches to water supply; or, as a minimum, (ii) an understanding of WSPs and risk-based approaches.

\section{C3. Project Appraisal}

The design and monitoring framework and its outputs could be tailored to develop performance targets and indicators that include a review of the WSP and its implementation. These performance indicators would be used to assess full WSP implementation by the proposed operating water utilities. In practice, much of this would be provided from the work undertaken under the project preparation phase so that the design and monitoring framework would largely be based around that earlier work.

While measuring performance of compliance with WQO is straightforward and can be achieved by routine water quality monitoring, it is more difficult to assess compliance with WSPs and pathogen reduction requirements. However, compliance with pathogen reduction requirements is largely assessed based on treatment performance, as assessed by operational monitoring, which is integrated within the WSP. In addition, compliance with WQO is assessed as part of the verification monitoring carried out within the WSP framework. Therefore, in general, setting performance objectives for WSP implementation could capture WQO and pathogen reduction compliance by default.

There are various guidelines and standards available that refer to WSPs, and even these can be open to various interpretations. It is important to clarify up front what the requirements are, so that a fair assessment can be conducted.

The first step in assessment is simply to check that the WSP has identified and addressed all of the relevant items in the guidance document that was identified in the TOR. The quality of the WSPs produced, whether as part of a technical assessment or other phases of projects, is not simple to assess quantitatively. Assessment is inevitably based on professional judgment and is usually carried out by a qualified and, in some cases, a registered auditor.

While too detailed to include in this Handbook, a guidance document relating to the assessment and auditing of WSPs has been developed by WHO as a tool to help guide the objective assessment of WSPs, ${ }^{9,10}$ and this is supported by an assessment software tool. In addition, an international scheme that maintains a register of WSP auditors qualified to assess the implementation of WSPs is operated by Exemplar Global, and there are a number of national schemes operating in specific jurisdictions."

9 WHO and IWA. 2013. Water Safety Plan Quality Assurance Tool. Geneva, Switzerland: WHO. http://www.who.int/water_ sanitation_health/publications/water-safety-quality-assurance/en/

10 WHO and IWA. 2015. A Practical Guide to Auditing Water Safety Plans. Geneva, Switzerland: WHO. http://www.who.int/water_ sanitation_health/dwq/audit-for-wsp.pdf

11 Exemplar Global. Water Quality Management System (WQMS) Auditor Certification. http://exemplarglobal.org/certification/ personnel-certification/quality-systems/water-quality-management-system-auditor/ 
The project administration manual (PAM) would incorporate the outputs and recommendations from the technical assessment with respect to WSPs. Primarily, the PAM would include the following:

- identification of the core WSP team in the project definition, as well as the anticipated impact and outcomes of establishing a formal (long-term) WSP approach;

- identification of the outputs that will be delivered by the core WSP team in the future-formal WSPs for each water supply utility and regular reviews;

- inclusion of additional finances for ADB to conduct the required WSP processes in the future;

- description of required WSP activity in the execution plan, which would closely follow the 11 steps set out in the WSP Manual (Figure 1); and

- inclusion of procedures and indicators in the performance monitoring and evaluation section with respect to the achievement of the processes and impacts of the WSP.

It is not anticipated that significant additional effort or resources, beyond what is already required of the ADB project management team, would be required to include this additional information in the PAM. Nonetheless, the document would include WSP requirements and allocate an appropriate budget.

For some projects there would be an overlap with the environmental safeguards, e.g., in relation to the identification of how the control measures will improve water quality, water efficiency, nonrevenue water, the catchment and system environment, and the environmental management plan.

In practice, it is not easy to integrate the WSP assessment into the PAM since at present there is no direct fit between the structure of the PAM and the WSP. Therefore, summaries of WSP activities need to be captured within the following sections of the PAM:

- Section II Implementation Plans

- Section III Project Management Arrangements

- Section VI Procurement and Consulting Services

- Section VIII Gender and Social Dimensions

- Section IX Performance Monitoring, Evaluation, Reporting and Communication

\section{PROJECT IMPLEMENTATION STAGE}

\section{D1. Role of the Client}

ADB's role is usually limited to the start-up phase of water projects. However, the water safety framework, including the WSP and surveillance activities, is intended to be a living and ongoing system. The WSP is intended to be a management system and would ideally be subject to periodic review, revision, and regulatory audit indefinitely.

With respect to the WSP, the water supplier's role is critical during implementation. At the implementation stage, a long-term WSP coordinating function or team could be established to implement and maintain the WSP. To support the goal of maximum ownership to the extent possible 
by those who will ultimately take over the WSP for the long term, the composition of the core WSP team that initially drives the design-build phase of a project, and the ongoing WSP coordinating function that will maintain the WSP for the long term, would overlap. The WSP would ultimately be owned by the counterpart water supplier (e.g., the water utility or local authority). The operational costs of maintaining a working WSP would need to include these management overheads.

In addition to the WSP and the water suppliers, the surveillance agency needs to provide a commitment to an indefinite realization of its oversight role in monitoring and auditing the work of the water supplier and the overall safety of the water supply system.

Ideally, local partners would demonstrate both the will and the capacity to maintain the WSP over the long term to avoid it becoming merely a design-stage risk assessment and management planning tool. A requirement by the long-term local partners to maintain the WSP would be sought, although this may need to be backed up by relevant capacity-building activities.

The formation of a team has been discussed repeatedly. Having such a team helps to ensure that the water supplier, ADB staff, and the borrower have a good understanding of their roles and responsibilities and accountability to other team members. There are no rigid requirements for team composition or structure, and there may be different ways to structure the expertise required based on the individual case and institutional structure of the utility.

\section{D2. Design Review}

The ADB project includes the recruitment of loan implementation personnel by the borrower for the design and implementation of the infrastructure activities recommended in the design report and contained in the report and recommendations to the President of ADB. The loan implementation team could include a technical expert in drinking-water safety and quality management, with solid WSP experience, so that they can assemble the core WSP team once significant investment in project infrastructure and capacity building has begun. The core WSP team will have the role of developing, implementing, monitoring, reviewing, and revising the WSP.

\section{D3. Review of Progress during Implementation}

The ADB project management team typically undertakes implementation review missions (at inception and twice per year during implementation) to monitor progress toward project completion. Such missions can include an additional requirement to review progress of the core WSP teams in establishing the WSP process. This could be conducted by ADB's own expert or an external expert who may be the same one who established the process at the project design stage.

Over time, difficulty with maintaining support for the WSP can arise due to the long time frame of ADB projects and discontinuities in staff roles. It can take some years at the start of an ADB project for resettlement, engineering design approvals, bidding document preparation, document processing, and construction. During the processing stage, stakeholders and partners may lose interest in WSP, and this can be exacerbated by changing incumbents and roles during project implementation. To help mitigate the risk of the WSP losing support, good agreements with counterpart agencies and stakeholders could be implemented up front to gain their commitment to WSP. In addition, a process for ongoing review of WSP activity is recommended, which would include assessment as part of the loan midterm review as well as potentially collaborative activities with $\mathrm{WHO}$ or local ministries of health or water supply to ensure continuity of the WSP efforts. 


\section{D4. Operations}

Where a loan is provided for operation of the water supply infrastructure, WSP components that need to be included within the operations phase of a project could be included within the conditions of the loan agreement.

As noted the task is less onerous than it may seem at first for design-build phase projects, since in most cases some, or even all, of the relevant WSP components will be addressed as part of the existing obligations associated with the project, for most components are inherent in good water operations.

However, to ensure that there are no significant gaps, delivery of the following WSP components could be promoted through the loan agreement:

- top-level commitment to adoption and implementation of a WSP and provision of safe water that meets the stated water quality objectives; ${ }^{12}$

- development of a WSP (or equivalent overarching document or set of documents) that describes how safe water is delivered;

- incorporation within the WSP (or equivalent) of the system description, risk assessment table, process control table, and validation, as developed under the design-build stage of the project; ${ }^{13}$

- operational monitoring program covering monitoring method and frequency for the operational monitoring parameters; ${ }^{14}$

- water quality verification monitoring program covering location and frequency of verification monitoring parameters; ${ }^{15}$

- documentation such as manuals and procedures for operations, maintenance, inspection, calibration, and corrective action;

- water quality emergency and incident response manual, including notification arrangements for the health authority;

- process for ensuring adequate operators with adequate skills, training, and competencies to operate the system; and

- review, reporting, internal and external auditing, and continuous improvement processes.

In practice, depending on the project's scope and stage of development, the ADB program might support just one part of the development of a WSP or the development and implementation of a complete WSP. Careful review of the WSP components against the scope of the ADB project is required, along with the exercise of discretion in deciding the scope of ADB support for WSP implementation for each project. In many contexts, the water supplier can be accountable for developing the full operational WSP; and if so, project monitoring and evaluation could assess WSP implementation by the service provider as a condition of the loan.

12 Examples are the board, chief executive, managing director, or president of a water company; mayor, councillors, or general manager of a local government water provider; and a community leader.

13 These may need to be updated or augmented over time in transitioning from design-build to operations as well as over time during operation of the system.

14 This would typically be cross-referenced to, or form part of, the process control table.

15 This would typically be cross-referenced to the water quality objectives for the project. 


\section{E. PROJECT COMPLETION AND EVALUATION STAGE}

Peer review and assessment processes could include assessment of the implementation of the WSP approach.

Project monitoring and evaluation over the first few years following project delivery would assess WSP implementation by the service provider. This will help ADB evaluate WSP sustainability within its projects.

There are some tools available to assist with such evaluations although these are intended for auditing rather than project assessment and may be somewhat more extensive than required in this case. ${ }^{16}$

\section{F. CHECKLIST}

To assist in evaluating whether specific aspects of WSPs relevant to the ADB project cycle have been addressed, the following checklist may prove a helpful start point:

\section{F1. Project Preparation Stage}

The WSP principles have been promoted and discussed with the counterparts in the context of the infrastructure's long-term operation.

\section{F2. Project Technical Assessment Stage}

A preliminary overview of the proposed infrastructure has been described, including maps, process flow diagrams, and process descriptions.

$\square$ A suitable core WSP team has been assembled, including representation from the local water supplier and surveillance agency if practicable, and has conducted a preliminary assessment of risks to drinking-water quality and tabulated those risks alongside the appropriate mitigating controls in a manner consistent with a WSP approach.

The design and monitoring framework and its outputs have been tailored to develop performance targets and indicators that include a review of the WSP and its implementation and that are included in the PAM or similar.

$\square \quad$ Implications for management procedures and supporting programs have been considered even if they are largely outside the scope of ADB's primary role.

16 See for instance WHO and IWA's A Practical Guide to Auditing Water Safety Plans (2015) and Water Safety Plan Quality Assurance Tool (2011). 


\section{F3. Project Implementation Stage}

The loan implementation includes a technical expert in drinking-water safety and quality management with solid WSP experience, that can assemble the ongoing WSP coordinating function in liaison with the operating water supplier and surveillance agency.

$\square$ The operating water supplier has been actively encouraged to agree to take on long-term ownership of a WSP (or equivalent) and to form an appropriate and accountable team in order to do that. This includes the full extent of the WSP, such as management procedures and supporting programs.

$\square \quad$ The surveillance agency has been actively encouraged to agree to take on long-term ownership of the surveillance (or equivalent) activities and to develop an appropriate formal arrangement in order to do that.

$\square$ Progress with WSP implementation and surveillance is reported on during implementation review missions.

\section{F4. Project Completion and Evaluation Stage}

Progress with WSP implementation and surveillance is reported during evaluation and review stages with lessons learned being captured for communication within ADB. These lessons would be shared among ADB staff to help with future projects.

\section{G. A STEP-BY-STEP GUIDE TO MAKING WATER SAFETY PLANS HAPPEN}

A step-by-step guide in Table 2 has been developed to illustrate the entire process of WSP development from commencement to completion. The guide is aimed at an ADB project officer for an example project.

In this Handbook, where responsibilities have been assigned to ADB, "ADB" can mean ADB staff, ADB partners, or ADB-appointed consultants. The table shows possible entry points and activities relating to the ADB project cycle and how they fit with the WSP activities. In practice, projects are often not as simple and do not follow the linear ideal that might be described in this Handbook. The step-by-step guide must be used intelligently and interpreted in the context of a specific project. Staff can review the guide and consider entry and exit points. Client buy-in is required at all steps in the process, and regular interaction is required with the intended long-term operational entity and overseeing health authority.

The definition of commencement and completion will vary by project depending on the agreements with the client. In the examples in this Handbook, ADB contribution to WSPs is restricted to the physical, operational, and institutional scope of work of the project. Components of the client's assets and systems that are outside the scope of ADB project may need to be included in the scope of a WSP, but this would not present obligations under WSP implementation. 
Table 2: Step-by-step Water Safety Plan Implementation Guide Summary for ADB Project Officer

\begin{tabular}{|c|c|c|c|c|}
\hline No. & $\begin{array}{l}\text { Illustrative Steps } \\
\text { and Deliverables }\end{array}$ & $\begin{array}{l}\text { Typical Party with } \\
\text { Responsibility for } \\
\text { Activities } \\
\text { (ADB can mean its } \\
\text { staff, partners, or } \\
\text { consultants) }\end{array}$ & $\begin{array}{l}\text { Typical Timing } \\
\text { Relating to ADB } \\
\text { Project Cycle }\end{array}$ & $\begin{array}{l}\text { Illustrative Notes } \\
\text { (For complete examples, refer to the Water } \\
\text { Safety Portal. http://www.wsportal.org) }\end{array}$ \\
\hline \multicolumn{5}{|c|}{ Define project limits and scope } \\
\hline 1 & $\begin{array}{l}\text { Define Project Scope } \\
\text { (Deliver: a statement } \\
\text { on the boundaries } \\
\text { between areas } \\
\text { of project and } \\
\text { WSP scope and } \\
\text { responsibility) }\end{array}$ & $\begin{array}{l}\text { ADB, co-financiers, and } \\
\text { client }\end{array}$ & $\begin{array}{l}\text { Initial } \\
\text { reconnaissance } \\
\text { Concept paper } \\
\text { stage } \\
\text { Loan fact-finding } \\
\text { Loan signing and } \\
\text { effectiveness }\end{array}$ & $\begin{array}{l}\text { Determine the respective physical, operational, and } \\
\text { institutional limits of the WSP. Options may include } \\
\text { the following: } \\
\text { (i) minimal: solely restricted to inside the limits and } \\
\text { scope of the project } \\
\text { (ii) broad: largely restricted to inside the limits } \\
\text { and scope, including additional elements that } \\
\text { consider the development, implementation, } \\
\text { and monitoring of the WSP, but that impute no } \\
\text { responsibilities for elements outside those limits } \\
\text { and scope } \\
\text { (iii) holistic: not restricted to inside the limits and } \\
\text { scope and impute responsibilities outside those } \\
\text { limits and scope for some WSP elements }\end{array}$ \\
\hline \multicolumn{5}{|c|}{ Describe the water supply system } \\
\hline 2 & $\begin{array}{l}\text { System Description } \\
\text { (Deliver: a summary } \\
\text { of the water supply } \\
\text { system) }\end{array}$ & ADB and client & $\begin{array}{l}\text { Project preparation } \\
\text { and technical due } \\
\text { diligence }\end{array}$ & $\begin{array}{l}\text { Develop a TOR for project and appoint project team. } \\
\text { Produce a water supply system description to cover } \\
\text { the physical infrastructure within the scope of the } \\
\text { ADB loan project. } \\
\text { Describe the source water catchment and reservoir or } \\
\text { aquifer, raw and treated water storage, treatment and } \\
\text { distribution infrastructure. } \\
\text { Provide supporting information including maps, } \\
\text { process descriptions, and summaries of historical } \\
\text { water quality data. } \\
\text { This information may need to extend beyond the ADB } \\
\text { project if required to describe the overall process and } \\
\text { if deemed to have system-wide relevance. }\end{array}$ \\
\hline 3 & $\begin{array}{l}\text { Process Flow } \\
\text { Diagram } \\
\text { (Deliver: a block } \\
\text { diagram of the water } \\
\text { supply system) }\end{array}$ & ADB and client & $\begin{array}{l}\text { Project preparation } \\
\text { and technical due } \\
\text { diligence }\end{array}$ & $\begin{array}{l}\text { Produce a process flow diagram to illustrate the } \\
\text { physical infrastructure that is within the scope of ADB } \\
\text { loan project. } \\
\text { If there are connected water source or transfer } \\
\text { components beyond the ADB project, these could } \\
\text { also be shown to help understand the overall process. }\end{array}$ \\
\hline
\end{tabular}


Table 2 continued

\begin{tabular}{|c|c|c|c|c|}
\hline No. & $\begin{array}{l}\text { Illustrative Steps } \\
\text { and Deliverables }\end{array}$ & $\begin{array}{l}\text { Typical Party with } \\
\text { Responsibility for } \\
\text { Activities } \\
\text { (ADB can mean its } \\
\text { staff, partners, or } \\
\text { consultants) }\end{array}$ & $\begin{array}{l}\text { Typical Timing } \\
\text { Relating to ADB } \\
\text { Project Cycle }\end{array}$ & $\begin{array}{l}\text { Illustrative Notes } \\
\text { (For complete examples, refer to the Water } \\
\text { Safety Portal. http://www.wsportal.org) }\end{array}$ \\
\hline 4 & $\begin{array}{l}\text { Water Quality } \\
\text { Objectives } \\
\text { (Deliver: a summary } \\
\text { of the drinking-water } \\
\text { guideline values and } \\
\text { standards that will } \\
\text { apply) }\end{array}$ & $\begin{array}{l}\text { ADB, co-financiers, and } \\
\text { client }\end{array}$ & $\begin{array}{l}\text { Project preparation } \\
\text { and technical due } \\
\text { diligence }\end{array}$ & $\begin{array}{l}\text { Form a core WSP team that will develop the WSP and } \\
\text { include parties that would ultimately take ownership } \\
\text { of it. That team would usually also take part in the risk } \\
\text { assessment with an expanded risk assessment team } \\
\text { (see step \#5). } \\
\text { Set out the health-related water quality objectives } \\
\text { (WQO). They may be the values included in national } \\
\text { drinking-water standards, or where resources are } \\
\text { available, the guideline values set out by WHO when it } \\
\text { is more stringent. } \\
\text { Aesthetic WQO can be set based on the utility's } \\
\text { agreed levels of service with the relevant authority. } \\
\text { For projects involving treatment, health-based } \\
\text { performance (treatment) targets may be established } \\
\text { for pathogens in treated water that are required to } \\
\text { meet the acceptable risk targets. For most projects } \\
\text { the acceptable risk target would be } 1 \text { additional annual } \\
\text { micro disability-adjusted life year ( } \mu \text { DALY) per person } \\
\text { as defined in Chapter } 3 \text { (Health-based targets) of the } \\
\text { WHO Guidelines for Drinking-water Quality. 4th ed. } \\
\text { (WHO, 2011). } \\
\text { Establishing treatment targets requires two steps: } \\
\text { (a) Estimate the pathogen concentrations in the } \\
\text { source waters. This estimate can be based on } \\
\text { local monitoring data but is more typically based } \\
\text { on published pathogen concentrations in similar } \\
\text { types of water sources. Default assumptions are } \\
\text { also included in the Guidelines for Drinking-water } \\
\text { Quality (Table 7.5). } \\
\text { (b) Define the pathogen reduction requirements } \\
\text { for bacteria, viruses, and protozoa that } \\
\text { would achieve the health-based targets and } \\
\text { associated operational monitoring requirements } \\
\text { reduction guidelines" in Part } 4 \text { of this Handbook. }\end{array}$ \\
\hline
\end{tabular}


Table 2 continued

\begin{tabular}{|c|c|c|c|c|}
\hline No. & $\begin{array}{l}\text { Illustrative Steps } \\
\text { and Deliverables }\end{array}$ & $\begin{array}{l}\text { Typical Party with } \\
\text { Responsibility for } \\
\text { Activities } \\
\text { (ADB can mean its } \\
\text { staff, partners, or } \\
\text { consultants) }\end{array}$ & $\begin{array}{l}\text { Typical Timing } \\
\text { Relating to ADB } \\
\text { Project Cycle }\end{array}$ & $\begin{array}{l}\text { Illustrative Notes } \\
\text { (For complete examples, refer to the Water } \\
\text { Safety Portal. http://www.wsportal.org) }\end{array}$ \\
\hline \multicolumn{5}{|c|}{ Conduct a drinking-water quality risk assessment } \\
\hline 5 & $\begin{array}{l}\text { Risk Assessment } \\
\text { Team } \\
\text { (Deliver: a table } \\
\text { summarizing the } \\
\text { group of people with } \\
\text { the expertise required } \\
\text { to assess water quality } \\
\text { risks) }\end{array}$ & ADB and client & $\begin{array}{l}\text { Project preparation } \\
\text { and technical due } \\
\text { diligence }\end{array}$ & $\begin{array}{l}\text { The risk assessment team could be led by a facilitator } \\
\text { reporting to the project manager. The team would } \\
\text { include system operators and technical experts. } \\
\text { The team would usually include the core WSP team } \\
\text { and may include representatives from a range of } \\
\text { parties such as the local water utility, management } \\
\text { decision makers, health ministry, local government, } \\
\text { WHO, ADB, and client. } \\
\text { Seeking and identifying suitable WHO contacts can } \\
\text { be achieved by contacting the local country office } \\
\text { or regional office. The up-to-date contact details for } \\
\text { each of the regional offices and country offices can } \\
\text { be found on the WHO website (http://www.who.int/ } \\
\text { about/en/) } \\
\text { The team is required to identify and assess risks and } \\
\text { agree on the controls required to manage those risks. }\end{array}$ \\
\hline 6 & $\begin{array}{l}\text { Risk Assessment } \\
\text { Report } \\
\text { (Deliver: a process } \\
\text { that will identify } \\
\text { and critically review } \\
\text { water quality risks } \\
\text { and produce a risk } \\
\text { summary table) }\end{array}$ & ADB and client & $\begin{array}{l}\text { Project preparation } \\
\text { and technical due } \\
\text { diligence }\end{array}$ & $\begin{array}{l}\text { A risk assessment table would be drafted and reviewed } \\
\text { by the risk assessment team using workshops, and } \\
\text { consensus would be reached. } \\
\text { The risk assessment table would be structured with } \\
\text { reference to the steps shown on the process flow } \\
\text { diagram. } \\
\text { The hazards and hazardous events that need to } \\
\text { be managed would be summarized along with any } \\
\text { existing and proposed risk mitigation processes, } \\
\text { collectively termed control measures. These } \\
\text { existing controls could be validated before the final } \\
\text { risk assessment as discussed in more detail under } \\
\text { Validation, item number nine of this table, below. } \\
\text { Evidence could be obtained to validate the } \\
\text { effectiveness of the existing control measures, and } \\
\text { preliminary estimates could be made of resulting } \\
\text { risk likelihoods and consequences within the project } \\
\text { context. }\end{array}$ \\
\hline
\end{tabular}


Table 2 continued

\begin{tabular}{|c|c|c|c|c|}
\hline No. & $\begin{array}{l}\text { Illustrative Steps } \\
\text { and Deliverables }\end{array}$ & $\begin{array}{l}\text { Typical Party with } \\
\text { Responsibility for } \\
\text { Activities } \\
\text { (ADB can mean its } \\
\text { staff, partners, or } \\
\text { consultants) }\end{array}$ & $\begin{array}{l}\text { Typical Timing } \\
\text { Relating to ADB } \\
\text { Project Cycle }\end{array}$ & $\begin{array}{l}\text { Illustrative Notes } \\
\text { (For complete examples, refer to the Water } \\
\text { Safety Portal. http://www.wsportal.org) }\end{array}$ \\
\hline & & & & $\begin{array}{l}\text { The selected control measures would ideally be fit } \\
\text { for purpose: effective, practical, affordable, reliable, } \\
\text { serviceable, and appropriate for the client's capacity } \\
\text { and resources, the context and complexity of the } \\
\text { project, the availability of existing and future data, and } \\
\text { the client's ability to implement the WSP and monitor } \\
\text { progress. } \\
\text { Note that it is important not to expend excessive effort } \\
\text { attempting to quantify risks since the focus of the } \\
\text { process would be on agreeing what control measures } \\
\text { are required to reduce risks to acceptable levels. } \\
\text { Improvement planning and follow-up actions could be } \\
\text { assigned time frames and accountabilities, and would } \\
\text { typically fall into two categories: } \\
\text { (i) investigation of uncertainties that make it hard to } \\
\text { assess risks or alternative control measures, and } \\
\text { (ii) implementation of new or augmented control } \\
\text { measures to reduce identified risks to acceptable } \\
\text { levels. }\end{array}$ \\
\hline \multicolumn{5}{|c|}{ Process control } \\
\hline 7 & $\begin{array}{l}\text { Control Measures } \\
\text { (Deliver: tables } \\
\text { summarizing the } \\
\text { processes and barriers } \\
\text { that reduce risks to } \\
\text { acceptable levels) }\end{array}$ & ADB and client & $\begin{array}{l}\text { Project preparation } \\
\text { and technical due } \\
\text { diligence }\end{array}$ & $\begin{array}{l}\text { Finalize the design of the control measures for } \\
\text { the process. These are usually the most important } \\
\text { physical control measures that are amenable to } \\
\text { frequent performance monitoring (ideally continuous } \\
\text { monitoring). Examples may include protected } \\
\text { water catchments and aquifers, secured bores } \\
\text { and raw water storages, raw water intake pumps, } \\
\text { coagulation-flocculation-sedimentation, filtration, } \\
\text { disinfection, closed treated water storage, continuous } \\
\text { pressurization, backflow prevention, and sanitary work } \\
\text { procedures. Control measures can also include non- } \\
\text { built components such as training, inspection, audit, } \\
\text { education, and procedures. }\end{array}$ \\
\hline 8 & $\begin{array}{l}\text { Operational } \\
\text { Monitoring } \\
\text { (Deliver: tables } \\
\text { summarizing the } \\
\text { operational monitoring } \\
\text { and performance } \\
\text { requirements of the } \\
\text { control measures) }\end{array}$ & ADB and client & $\begin{array}{l}\text { Project preparation } \\
\text { and technical due } \\
\text { diligence }\end{array}$ & $\begin{array}{l}\text { For the key control measures, define operational } \\
\text { monitoring parameters and set performance limits on } \\
\text { those parameters. Examples include individual filtered } \\
\text { water turbidity targets and disinfectant doses. } \\
\text { Prepare process control tables that clearly set out } \\
\text { - operational monitoring parameters, locations, } \\
\text { frequencies, and responsible parties; } \\
\text { - operational limits (within which the process is } \\
\text { performing as intended); } \\
\text { corrective actions (to respond to deviation outside } \\
\text { operational limits); and } \\
\text { critical limits (pass or fail operational limits that } \\
\text { are applicable to some of the most critical control } \\
\text { measures). }\end{array}$ \\
\hline
\end{tabular}


Table 2 continued

\begin{tabular}{|c|c|c|c|c|}
\hline No. & $\begin{array}{l}\text { Illustrative Steps } \\
\text { and Deliverables }\end{array}$ & $\begin{array}{l}\text { Typical Party with } \\
\text { Responsibility for } \\
\text { Activities } \\
\text { (ADB can mean its } \\
\text { staff, partners, or } \\
\text { consultants) }\end{array}$ & $\begin{array}{l}\text { Typical Timing } \\
\text { Relating to ADB } \\
\text { Project Cycle }\end{array}$ & $\begin{array}{l}\text { Illustrative Notes } \\
\text { (For complete examples, refer to the Water } \\
\text { Safety Portal. http://www.wsportal.org) }\end{array}$ \\
\hline 9 & $\begin{array}{l}\text { Validation } \\
\text { (Deliver: statement on } \\
\text { the technical veracity } \\
\text { of the process control } \\
\text { limits set for the } \\
\text { control measures) }\end{array}$ & $A D B$ & $\begin{array}{l}\text { Project } \\
\text { implementation } \\
\text { (domestic } \\
\text { engineering design } \\
\text { approval) }\end{array}$ & $\begin{array}{l}\text { Set out the objective evidence for the technical } \\
\text { validity of the selected operational and critical limits } \\
\text { explaining how the processes when operating within } \\
\text { those limits are adequate for controlling identified } \\
\text { hazards and keeping risks at acceptable levels. } \\
\text { Justify the adequacy of associated operational } \\
\text { monitoring methods and frequencies and the } \\
\text { corrective actions from the perspective of ensuring } \\
\text { reliable process control. } \\
\text { This validation process could consider both technical } \\
\text { validity and practical achievability. }\end{array}$ \\
\hline 10 & $\begin{array}{l}\text { Documentation and } \\
\text { Records } \\
\text { (Deliver: manuals, } \\
\text { procedures, and } \\
\text { forms) }\end{array}$ & ADB and client & $\begin{array}{l}\text { Project } \\
\text { implementation } \\
\text { (domestic } \\
\text { engineering design } \\
\text { approval) }\end{array}$ & $\begin{array}{l}\text { Prepare realistic, user-targeted operations manuals, } \\
\text { standard operating procedures, and record-keeping } \\
\text { forms. } \\
\text { The format and style ought to be suitable for ready } \\
\text { interpretation and use by client staff, given their level } \\
\text { of expertise and training, and the local needs. }\end{array}$ \\
\hline \multicolumn{5}{|c|}{ Oversight } \\
\hline 11 & $\begin{array}{l}\text { Surveillance } \\
\text { (Deliver: schedule for } \\
\text { verification testing and } \\
\text { auditing to confirm } \\
\text { WSP implementation) }\end{array}$ & $\begin{array}{l}\text { Surveillance agency and } \\
\text { client }\end{array}$ & $\begin{array}{l}\text { Project } \\
\text { implementation } \\
\text { (domestic } \\
\text { engineering design } \\
\text { approval) }\end{array}$ & $\begin{array}{l}\text { Design a long-term verification monitoring program } \\
\text { for the water supply that includes microbial } \\
\text { and chemical water quality testing of samples } \\
\text { representative of supply to customers to assess } \\
\text { compliance with the WQO. } \\
\text { Design a long-term verification monitoring program } \\
\text { for the water supply that includes measures of } \\
\text { customer or consumer satisfaction to assess } \\
\text { acceptability of the water supply. } \\
\text { Optional (if agreed with the client): Set out an } \\
\text { internal and external audit program devised to provide } \\
\text { assurance of adherence of client to the WSP and } \\
\text { subordinate documents such as compliance with } \\
\text { process control tables, operations manuals, and } \\
\text { standard operating procedures based on auditing } \\
\text { record-keeping forms. }\end{array}$ \\
\hline
\end{tabular}


Table 2 continued

\begin{tabular}{|c|c|c|c|c|}
\hline No. & $\begin{array}{l}\text { Illustrative Steps } \\
\text { and Deliverables }\end{array}$ & $\begin{array}{l}\text { Typical Party with } \\
\text { Responsibility for } \\
\text { Activities } \\
\text { (ADB can mean its } \\
\text { staff, partners, or } \\
\text { consultants) }\end{array}$ & $\begin{array}{l}\text { Typical Timing } \\
\text { Relating to ADB } \\
\text { Project Cycle }\end{array}$ & $\begin{array}{l}\text { Illustrative Notes } \\
\text { (For complete examples, refer to the Water } \\
\text { Safety Portal. http://www.wsportal.org) }\end{array}$ \\
\hline \multicolumn{5}{|c|}{ Handover } \\
\hline 12 & $\begin{array}{l}\text { Water Safety Plan } \\
\text { (Deliver: consolidation } \\
\text { of the core of the } \\
\text { WSP into a single } \\
\text { document) }\end{array}$ & Client & $\begin{array}{l}\text { Project } \\
\text { implementation } \\
\text { (construction } \\
\text { completion and } \\
\text { commissioning) }\end{array}$ & $\begin{array}{l}\text { Consolidate WSP in close liaison with client. } \\
\text { Improvement actions could be collated into a } \\
\text { summary table to draw on improvements identified } \\
\text { from work to date. Note that this includes those } \\
\text { improvements identified throughout the completion } \\
\text { of the steps of developing the WSP. } \\
\text { Document format and style would be suitable for } \\
\text { ready interpretation and use by client staff, given their } \\
\text { level of expertise and training. }\end{array}$ \\
\hline 13 & $\begin{array}{l}\text { Management } \\
\text { Procedures and } \\
\text { Supporting Programs } \\
\text { (Deliver: supporting } \\
\text { activities that } \\
\text { underpin the WSP) }\end{array}$ & Client & $\begin{array}{l}\text { Project } \\
\text { implementation } \\
\text { (construction } \\
\text { completion and } \\
\text { commissioning) }\end{array}$ & $\begin{array}{l}\text { As part of consolidating and finalizing the WSP, } \\
\text { important management procedures and supporting } \\
\text { programs could be identified and reviewed within the } \\
\text { client's current processes. Examples may include } \\
\text { incident and emergency response plans, } \\
\text { training programs, } \\
\text { documentation and records of management } \\
\text { processes, and } \\
\text { communication and community consultation } \\
\text { processes. } \\
\text { Cross-references could be made to those } \\
\text { management procedures and supporting programs } \\
\text { within the WSP. } \\
\text { Gaps and weaknesses within management procedures } \\
\text { and supporting programs could be identified, and } \\
\text { advocacy and advice on improvements could be } \\
\text { provided. } \\
\text { Actions could be agreed with the client to address } \\
\text { gaps and weaknesses summarized in the improvement } \\
\text { actions table of the WSP. }\end{array}$ \\
\hline 14 & $\begin{array}{l}\text { Handover Training } \\
\text { (Deliver: training } \\
\text { sufficient to ensure } \\
\text { client understanding } \\
\text { of WSPs) }\end{array}$ & Client & $\begin{array}{l}\text { Project } \\
\text { implementation } \\
\text { (construction } \\
\text { completion and } \\
\text { commissioning) }\end{array}$ & $\begin{array}{l}\text { Training and competency assessment could be } \\
\text { provided to complete and verify handover of the WSP, } \\
\text { including the supporting programs to the client to } \\
\text { ensure understanding of systems and ongoing role in } \\
\text { ensuring water safety. } \\
\text { If required and if WSP is quite new to them, an } \\
\text { advocacy activity could be undertaken with the } \\
\text { Ministry of Health to ensure understanding of their } \\
\text { ongoing role in assuring water safety. This advocacy } \\
\text { activity may need to be started up front, prior to } \\
\text { beginning the WSP, as well as be part of handing it } \\
\text { over. }\end{array}$ \\
\hline
\end{tabular}


Table 2 continued

\begin{tabular}{|c|c|c|c|c|}
\hline No. & $\begin{array}{l}\text { Illustrative Steps } \\
\text { and Deliverables }\end{array}$ & $\begin{array}{l}\text { Typical Party with } \\
\text { Responsibility for } \\
\text { Activities } \\
\text { (ADB can mean its } \\
\text { staff, partners, or } \\
\text { consultants) }\end{array}$ & $\begin{array}{l}\text { Typical Timing } \\
\text { Relating to ADB } \\
\text { Project Cycle }\end{array}$ & $\begin{array}{l}\text { Illustrative Notes } \\
\text { (For complete examples, refer to the Water } \\
\text { Safety Portal. http://www.wsportal.org) }\end{array}$ \\
\hline \multicolumn{5}{|c|}{ Follow up } \\
\hline 15 & $\begin{array}{l}\text { Post-implementation } \\
\text { Review } \\
\text { (Deliver: following } \\
\text { up to help learn } \\
\text { lessons and reporting } \\
\text { to ADB on how this } \\
\text { can improve future } \\
\text { projects) }\end{array}$ & $\mathrm{ADB}$ and client & $\begin{array}{l}\text { Project } \\
\text { implementation } \\
\text { (construction } \\
\text { completion and } \\
\text { commissioning) }\end{array}$ & $\begin{array}{l}\text { A post-implementation review of WSP could be } \\
\text { undertaken, including the surveillance program and } \\
\text { supporting programs components (preferably in } \\
\text { liaison with the Ministry of Health) within } 2 \text { years after } \\
\text { project handover. } \\
\text { Improvement opportunities could be identified, and, } \\
\text { where possible, lessons of relevance to future ADB } \\
\text { projects could be documented and communicated } \\
\text { with ADB. }\end{array}$ \\
\hline
\end{tabular}

$\mathrm{ADB}=$ Asian Development Bank, $\mathrm{TOR}=$ terms of reference, $\mathrm{WHO}=$ World Health Organization, WSP = Water Safety Plan.

\section{H. INDICATORS OF WATER SAFETY PLAN IMPLEMENTATION AND THEIR ASSESSMENT}

The key indicators to consider when reviewing a WSP are outlined as follows:

- Firstly, how much of the WSP has been developed and implemented. A number of tools and guidelines have been developed for the assessment of WSP implementation including the WHO's WSP audit guidance. ${ }^{17}$ These tools were developed to provide a means for objective assessment of implementation of WSPs. Some of the tools were set up originally for utilities or regulators to measure progress and identify areas that need further attention, but they can equally be used for external review by other parties. Using a common tool internally and externally allows discussion from a common perspective at that level of implementation.

- Secondly, and although to some extent going beyond the core of a WSP, the extent to which the key components of an operation and maintenance plan have been achieved to ensure that delivery of safe water has been implemented and is operational, including the following:

$>$ Standard operating procedures for operation of water supply system from catchment to customer, including operational manuals

$>$ Procedures for programmed and unscheduled (emergency) maintenance activities

$>$ Emergency and incident management protocols and manuals

$>$ Equipment calibration and maintenance programs

$>$ Asset information data capture and management systems

$>$ Key performance indicators (KPI)

$>$ Monitoring and reporting of KPI (government-regulated or self-regulated)

$>$ Long-term asset management strategy and funding arrangements

$>$ Staff and contractor training program

17 WHO and IWA. 2015. A Practical Guide to Auditing Water Safety Plans. Geneva, Switzerland: WHO. http://www.wsportal.org/resource/a-practical-guideto-auditing-water-safety-plans/ 
$>$ Quality control and quality assurance systems, internal and third party auditing of operation and maintenance activities and KPIs

$>$ Outcome-based indicators (water quality data, water quality itself, operational efficiency, and diarrheal outbreaks, as the case may be).

Existing assessment tools were largely intended to evaluate the retrospective performance of a water utility in adhering to its WSP, but they can also be used, with appropriate interpretation, to assess WSP creation and development. The key feature of these assessment tools is a series of questions that, if answered, provide information on the implementation of a WSP by a utility. Examples of assessment questions are as follows:

- Has the WSP been completed, addressing all the steps of the appropriate WSP guidance document?

- Has the utility adhered to the WSP document in practice, or has the WSP document become outof-date or irrelevant?

- Is the WSP up-to-date and subject to iterative and full updates at intervals and in response to changed circumstances?

- Is the WSP coordinating function or team adequate to reliably and objectively identify and assess risks and the required process controls?

- Have sufficient process controls been put in place to adequately mitigate identified significant risks?

- Have improvement actions been undertaken to address situations where process controls were considered inadequate?

- Have the process controls been described in sufficient detail?

- Have process control critical limits and target criteria been validated against objective evidence as being sufficiently effective at controlling identified hazards?

- Have procedures been developed for the operation of process controls, including information on target criteria and critical limits, operational monitoring, corrective actions, and record keeping?

- Has the accuracy of monitoring systems been checked, and have corrective actions been taken, if required, to ensure that monitoring results are accurate?

- Have the monitoring systems been calibrated at a suitable frequency against suitable reference standards?

- Have incident and emergency management procedures been developed in response to the full range of reasonably foreseeable incidence and emergencies affecting the subject water supply?

- Has verification monitoring taken place for a suitable range of determinants at a suitable frequency?

- Are corrective action procedures in place to deal with adverse results arising from verification monitoring?

- Have records been kept of operational and verification monitoring and of customer feedback related to water quality?

- Are reliable record keeping and documentation processes in place for the WSP? 


\section{PART 3}

TEMPLATES

\section{A. WATER SAFETY PLAN DOCUMENT}

A WSP is delivered as a document. An example WSP document, including front cover and table of contents, is given in Figure 3. The document is intended to be created and implemented by any organization that supplies water to others. It shows who within the organization will oversee the development and implementation of the WSP, as well as who is responsible for particular activities identified under the WSP.

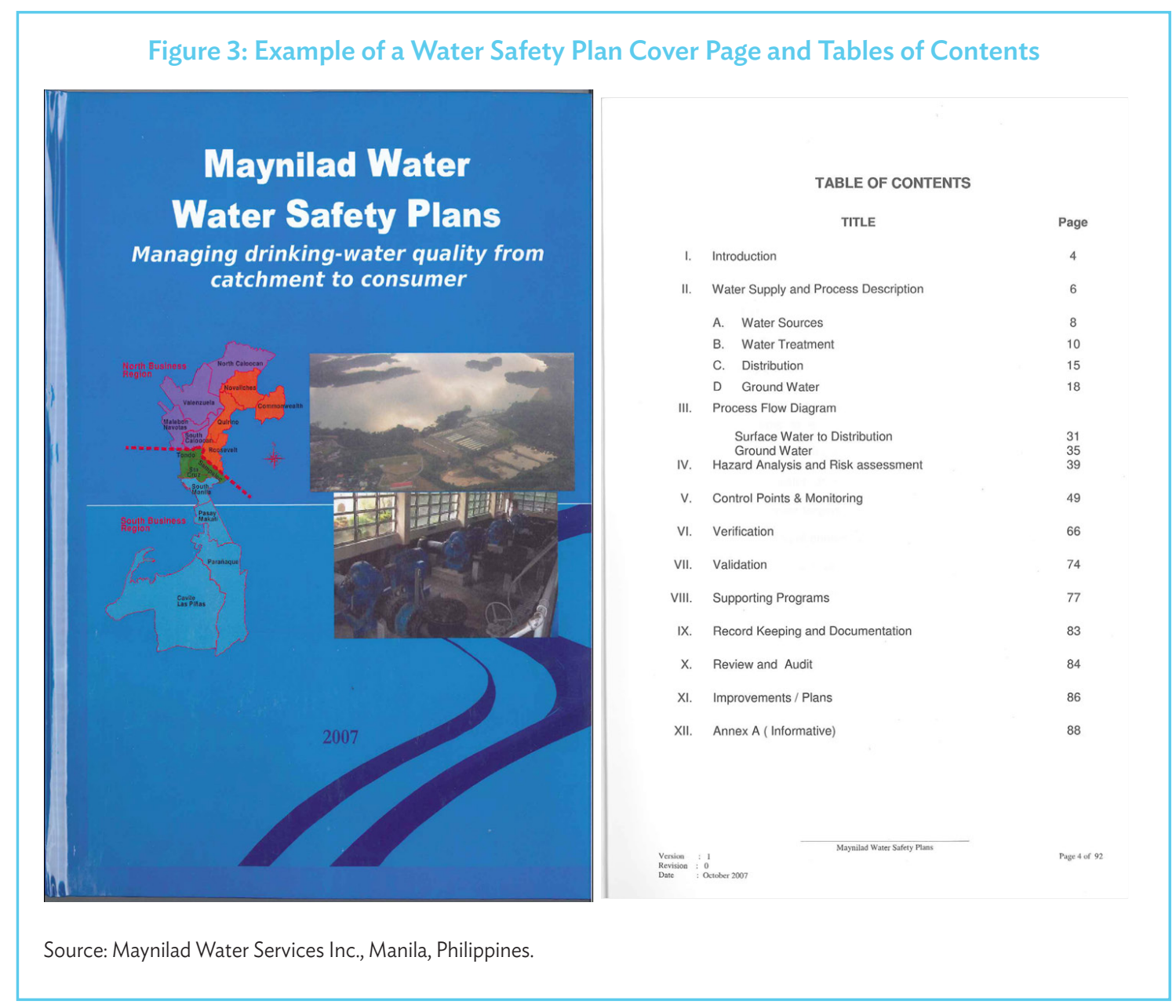




\section{B. SAMPLE DESIGN AND MONITORING FRAMEWORK FOR AN ADB PROJECT}

An overview as to how a WSP could be reflected in a project's design and monitoring framework is given in Table 3.

Table 3: Overview of Water Safety Plan in Project Design and Monitoring Framework

\begin{tabular}{|c|c|c|}
\hline Results Chain & $\begin{array}{l}\text { Examples of Possible } \\
\text { Performance Targets and } \\
\text { Indicators }\end{array}$ & $\begin{array}{l}\text { Data Source or Reporting } \\
\text { Mechanism }\end{array}$ \\
\hline $\begin{array}{l}\text { Outcome } \\
\text { Sustainable provision of safe water } \\
\text { and improved operational efficiencies }\end{array}$ & $\begin{array}{l}\text { Reduced incidence of diarrheal } \\
\text { outbreaks } \\
\text { Reduced physical burden } \\
\text { Improved water quality } \\
\text { Improved operational efficiency } \\
\text { Customer satisfaction } \\
\text { Higher tariffs and collection rates }\end{array}$ & $\begin{array}{l}\text { National health data } \\
\text { Impact studies } \\
\text { Water quality data reports } \\
\text { WSP monitoring reports }\end{array}$ \\
\hline $\begin{array}{l}\text { Output } \\
\text { Expanded or rehabilitated } \\
\text { infrastructure (including specific } \\
\text { investments to reduce risks and } \\
\text { hazards to water quality) } \\
\text { Improved capacity (risk } \\
\text { management, water safety } \\
\text { management, and operational } \\
\text { capacity) }\end{array}$ & $\begin{array}{l}\text { WSPs } \\
\text { Long-term asset management } \\
\text { strategy and funding arrangements } \\
\text { Quality control and quality } \\
\text { Assurance systems, internal and third } \\
\text { party } \\
\text { Auditing of operation and } \\
\text { maintenance activities and key } \\
\text { performance indicators } \\
\text { Improved water quality data }\end{array}$ & Utility reports \\
\hline $\begin{array}{l}\text { Key Activities } \\
\text { Staff and contractor training } \\
\text { programs } \\
\text { Standard operating procedures of } \\
\text { water supply system from catchment } \\
\text { to customer, including operational } \\
\text { manuals }\end{array}$ & \multirow[t]{5}{*}{$\begin{array}{l}\text { Training reports, manuals, and } \\
\text { monitoring reports }\end{array}$} & \multirow[t]{5}{*}{$\begin{array}{l}\text { Training and competency } \\
\text { assessments } \\
\text { Log books } \\
\text { Asset management and maintenance } \\
\text { records }\end{array}$} \\
\hline $\begin{array}{l}\text { Procedures for programmed } \\
\text { and unscheduled (emergency) } \\
\text { maintenance activities }\end{array}$ & & \\
\hline $\begin{array}{l}\text { Emergency and incident } \\
\text { management protocols and manuals }\end{array}$ & & \\
\hline $\begin{array}{l}\text { Equipment calibration and } \\
\text { maintenance programs }\end{array}$ & & \\
\hline $\begin{array}{l}\text { Asset information data capture and } \\
\text { management systems }\end{array}$ & & \\
\hline
\end{tabular}

WSP = Water Safety Plan

Source: Partly based on ADB. 2016. Guidelines for Preparing a Design and Monitoring Framework. Manila, Philippines: ADB. https:// www.adb.org/documents/guidelines-preparing-design-and-monitoring-framework 


\section{TERMS OF REFERENCE FOR A WATER SAFETY PLAN EXPERT}

This example provides a model terms of reference (TOR) that can be used to define the scope of work of a WSP expert to be engaged as part of the project preparatory technical assistance (PPTA) team. The example is drawn from the draft ADB Guidance Note on Mainstreaming Water Safety Plans in ADB Projects. ${ }^{18}$

\section{Scope of Work for Preparatory Phases}

\section{Assemble a core WSP team comprising}

a. water quality management expert, ideally a person experienced in WSP implementation, and other water engineering and quality experts within the implementing team;

b. representatives from existing local water supplier, including engineers and any water quality staff;

c. representative(s) of government agencies responsible for standards and regulation of drinking-water quality and surveillance; and

d. representative(s) of government agencies responsible for urban infrastructure investment policy and regulation of utilities.

2. Coordinate a workshop with the above stakeholders and at least one member of ADB's project team to ensure they are appropriately briefed in the concept and process for conducting future appraisal, monitoring, and evaluation activities, and to discuss the

a. concept of WSPs, their benefits (provide presentation), and how they are developed and implemented;

b. existing water supply system and drinking-water quality control measures (engineers from individual utilities could be encouraged to present);

c. existing situation with respect to water safety (incidence, location, and source of known water safety failures and problems); and

d. apparent actions required for the improvement of water safety either by the water utility or others.

3. Conduct one or more initial system assessment(s). This includes high-level descriptions of the existing (or proposed) water supply systems, including flow charts showing sources, control points, and receptors. This will need to be done separately for each water supply utility, but need not be highly detailed at this stage of project preparation. The basic elements for describing the water supply system would cover the whole system from the source (catchment) to the end point of supply (the customer), and document the inputs and outputs even if they do not operate all the time. The flow diagram could be taken on-site to check its accuracy and local knowledge.

4. Oversee a workshop to undertake high-level risk assessment for the preparation of a preliminary WSP to the extent practicable for the stage at which the project is. This would establish the

a. sources of risk to water safety in the region;

b. potential biological, physical, and chemical hazards to water safety along the system, and risk assessment;

c. current control measures for those risks and effectiveness of those controls;

18 Guidance Note on Mainstreaming Water Safety Plans in ADB Projects (unpublished). 
d. residual risks that are not controlled;

e. required action for improvements such as developing enhanced controls;

f. indicators by which drinking-water safety improvements will be measured;

g. level and responsibilities of ongoing WSP coordinating functions or teams; and

h. cost implications of any of the recommendations proposed including for any goods, equipment, capacity building during project implementation (expressed in capital and recurrent costs).

9. Ensure that the interim WSP will identify the need for institutional capacity and infrastructure improvements (in the water sector and elsewhere) to improve water safety. There is a need to incorporate the findings of the WSP into the wider work of the PPTA team with respect to project design and costing for urban infrastructure and environmental improvements. The PPTA team could also make recommendations of the indicators by which the success of the project can be measured in terms of the following:

a. process: uptake of the WSP

b. impacts: beneficial outcomes in terms of improved water safety (e.g., percentage of drinkingwater quality samples meeting standards, number of incidents requiring provision of alternative water supplies, number and duration of treatment plant failures, proportion of the community receiving continually pressurized water)

3. Coordinate the work undertaken as part of the environmental and social impact assessments, including the health impact assessment, with the work related to the preparation of the WSP. The drinking-water quality expert could coordinate with other PPTA team personnel responsible for managing aspects such as the
a. environmental and social impact assessments,
b. environmental monitoring plan,
c. summary poverty reduction,
d. social strategy, and
e. social action plans.

\section{Scope of Work for Implementation Phase}

The drinking-water quality expert is responsible for the following:

1. Assemble the required individuals and stakeholders for the ongoing WSP coordination and maintenance person(s) or teams in each water supply utility.

2. Provide appropriate training as required by the ongoing WSP coordination and maintenance person(s) or teams to cover the concept and implementation of WSPs.

3. Work with the ongoing WSP coordination and maintenance person(s) or teams to
a. undertake a revised system assessment (based on the status of infrastructure or institutions following project investment) including any new system aspects and control measures now in place;
b. undertake a revised risk assessment of the water supply and safety system and initiate the required monitoring program for evaluating water safety in the future; and
c. review the team's WSP outputs and identify control measures to mitigate the potential hazards identified.

4. Conduct a review of the WSP six months and one year after its completion. This would include checks to ensure the WSP is being reviewed as necessary and the monitoring procedures contained within it are being implemented. This would also include review of construction of 
control measures where included and of the core WSP team's own operational monitoring plans. This would be reported to ADB for inclusion in the project monitoring or project midterm and project completion reports.

\section{Resource Requirements and Deliverables}

In addition to remuneration, the personnel involved will require resources for one to two in-country visits and technical translation support for the two workshops and translation of reports.

Additional resource requirements need to be considered for the appraisal, implementation, and valuation phases.

The tasks and inputs to complete the assignment required for an early phase WSP are given in Table 4. They are only estimates of what may be required and are based on experience with implementing a WSP as part of an ADB project for a water supply system. These estimates need to be critically reviewed and revised in accordance with the actual project scope.

\section{Table 4: Tasks and Approximate Inputs for an Early Phase Water Safety Plan}

\begin{tabular}{|c|c|c|}
\hline Tasks & Inputs (Days) & Outputs \\
\hline $\begin{array}{l}\text { Assembly of core WSP team and provision of } \\
\text { required information and briefing material to } \\
\text { the team }\end{array}$ & 3 days & $\begin{array}{l}\text { Report detailing core WSP team members, } \\
\text { roles, and responsibilities, including all the } \\
\text { briefing materials, agreements made, and } \\
\text { work plan }\end{array}$ \\
\hline $\begin{array}{l}\text { Two in-country workshops (one day each) led } \\
\text { by expert and attended by local stakeholders }\end{array}$ & $\begin{array}{l}2 \text { days for workshops } \\
\text { with } 4 \text { days } \\
\text { preparation }\end{array}$ & Workshop report and training manual \\
\hline $\begin{array}{l}\text { Initial system assessment and completion of } \\
\text { interim WSP (following second workshop), and } \\
\text { incorporation into wider project design }\end{array}$ & 12 days & $\begin{array}{l}\text { System assessment, interim WSP, and } \\
\text { incorporation of findings into other outputs } \\
\text { and reporting }\end{array}$ \\
\hline $\begin{array}{l}\text { Travel days, report writing, meetings, and } \\
\text { review }\end{array}$ & 5 days & Final WSP and final reporting \\
\hline Total Inputs & 22 days & \\
\hline
\end{tabular}

WSP = Water Safety Plan

The following WSP components could be delivered:

1. System assessment

- System description ${ }^{19}$

- general description of the drinking-water supply system

- process and system description

- process flow diagram

- sanitary survey and inspection of environments that are potential pollution sources

- historical water quality data analysis

- $\quad$ summary of the required WQO

19 This largely occurs in any project, but some parts could be missed or completed inadequately in some projects. 
- Risk assessment table 20 that summarizes

- hazards

- hazardous events

- control measures (these may include both existing and proposed control measures, as applicable)

- risks (qualitative risk assessment)

- assessment of the adequacy of controls

- identification of major uncertainties that need investigation

- improvements to control measures

2. Process control table

- list of important control measures

- identification and specification of the

- design criteria

- operational monitoring parameters

- operational and critical limits of operational monitoring parameters

- corrective actions including alternative supply options if critical limits are breached

- validation of the adequacy of the control measures ${ }^{21}$

- surveillance program for implementation by the surveillance agency

- sustainability evaluation that assesses the readiness of counterpart entities, such as water utilities, to implement the required principles and controls in the long term

The credentials and roles of the core WSP team could be described in some detail, as given in Table 5 .

\section{Table 5: Credentials and Roles of the Core Water Safety Plan Team}

\begin{tabular}{|c|c|c|}
\hline Example Job Title & Example Expertise & Example Role \\
\hline Team leader & $\begin{array}{l}\text { Water quality science, engineering, or } \\
\text { management }\end{array}$ & $\begin{array}{l}\text { Leading WSP } \\
\text { development }\end{array}$ \\
\hline Water operators & $\begin{array}{l}\text { Covering catchments, source water reservoirs or } \\
\text { aquifers, headworks or bores, treatment plants } \\
\text { and networks, as applicable }\end{array}$ & $\begin{array}{l}\text { Implementation and } \\
\text { input into WSP }\end{array}$ \\
\hline $\begin{array}{l}\text { Risk assessment and } \\
\text { management system } \\
\text { facilitator }\end{array}$ & $\begin{array}{l}\text { Facilitation and project management of risk- } \\
\text { based product quality management systems } \\
\text { such as WSPs }\end{array}$ & $\begin{array}{l}\text { Facilitation of risk } \\
\text { assessments and } \\
\text { detailed development } \\
\text { of WSP }\end{array}$ \\
\hline Process technician & Water treatment specialist & Input into WSP \\
\hline
\end{tabular}

continued on next page

20 This would typically be developed by a risk assessment team that includes health authority, system designers, and representatives of the intended system operators.

21 This would typically explicitly reference and validate the critical limits against objective evidence such as industry standards and manuals. 
Table 5 continued

\begin{tabular}{|l|l|l|}
\hline Example Job Title & Example Expertise & Example Role \\
\hline Water scientist & Microbiology or Chemistry & $\begin{array}{l}\text { Monitoring of WSP } \\
\text { effectiveness }\end{array}$ \\
\hline Public health professional & Epidemiology or health risk assessment & $\begin{array}{l}\text { Verifying links } \\
\text { between risk factors, } \\
\text { interventions, and } \\
\text { health outcomes }\end{array}$ \\
\hline
\end{tabular}

WSP $=$ Water Safety Plan.

\section{Qualifications and Experience}

The technical expert in drinking-water quality management should have a degree in science, engineering, medicine, or other relevant discipline and a postgraduate degree in a subject relevant to water quality monitoring. That person should have at least 15 years of relevant sector experience, including at least 5 years' experience in water safety planning. The expert should be able to demonstrate previous experience in leading the preparation of WSPs. Experience in preparing projects for multilateral finance institutions or donor projects is required, and experience in ADB projects would be an advantage. Knowledge of the country and past experience in the water quality monitoring in the country or region is preferred. Excellent spoken and written English is required, and knowledge of the local language is preferable.

A WSP would be implemented over multiple phases as part of an ADB water project. The approximate time frame and human resource requirements to complete a WSP are illustrated in Figure 4. These estimated values will vary depending on the complexity of the project and its duration.

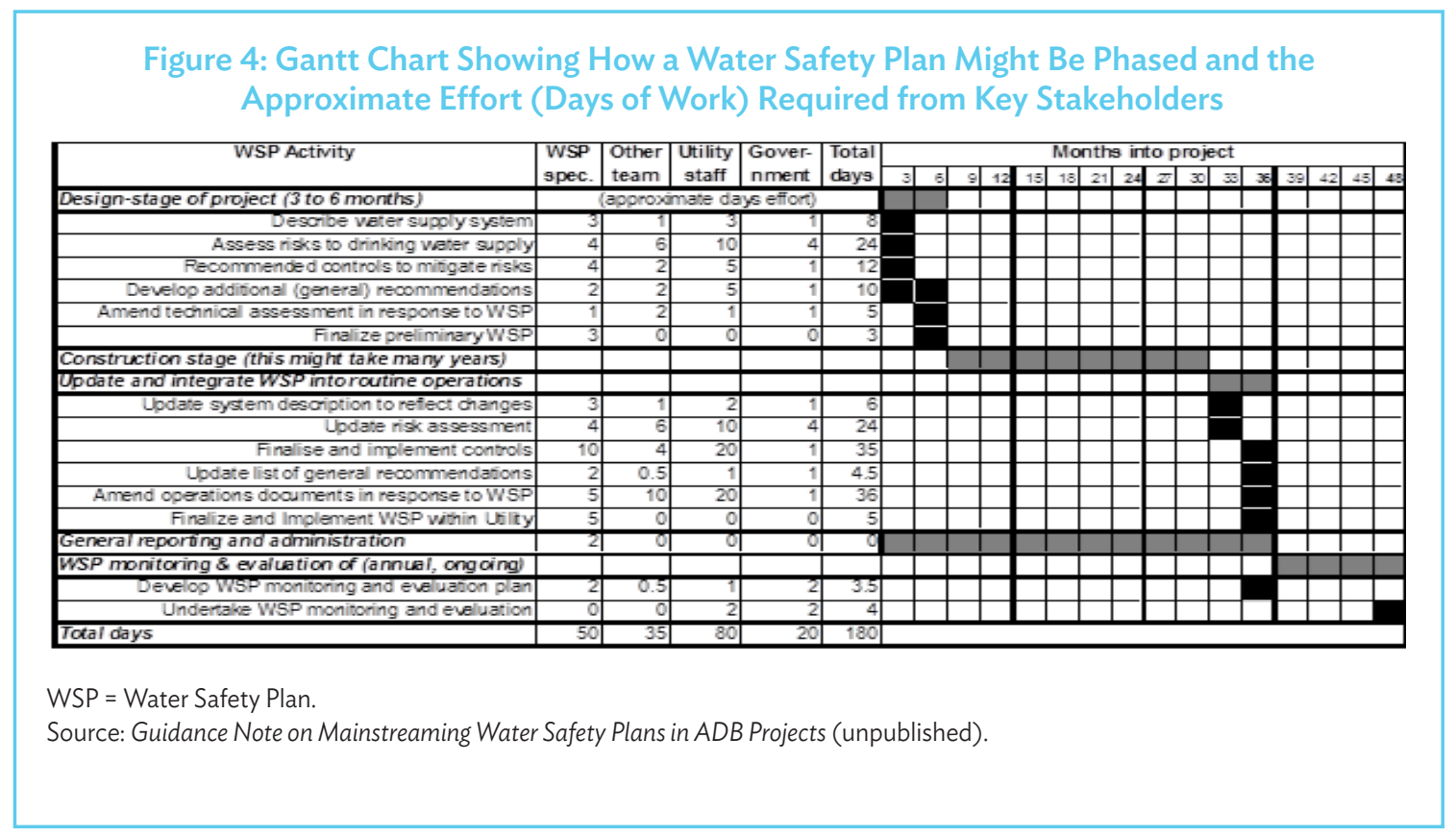




\section{Selection Criteria}

To be selected as a WSP technical expert, the person should have a number of key capabilities and experiences. The following areas of expertise could be covered so far as is reasonably practicable:

- Experience and technical understanding of drinking-water quality and safety (water quality guidelines and standards, water microbiology and chemistry), water infrastructure (source and catchment management, water treatment, water distribution, plumbing, conveyance, storage), and use and acceptability aspects of water for customers.

- Experience and understanding of WSPs or similar systematic risk assessment, risk management, and process control systems such as equivalents of WSPs in other jurisdictions and/or Hazard Analysis and Critical Control Points (HACCP) systems.

In addition, general criteria in selecting a WSP implementation person include the following:

- Ability to coordinate people and to collate and synthesize inputs from a range of people and sources.

- Ability to converse fluently in the local language or to have full access to a person able to provide translation. Note that technical translation capability is essential, as there are many jargons in the water sector and it is highly likely -if only general translators are used - that key and technically important messages will be mistranslated, resulting in potentially dangerous misunderstandings.

- Availability to the project-this usually rules out persons substantively employed, such as in government or university posts, and necessitates using consultants or contractors. Government or university staff prepared to take short-term assignments can be useful to fill short-term, specific roles in projects, but a WSP may require inputs over several years and, in some cases, long stints of activity at a time.

- Ability to work with people from different cultural backgrounds. In some contexts, this may rule out certain persons, which is not entirely consistent with broader ADB policies. For instance, experts that have a long and active history of conflict with those supporting the project might find it difficult to gain acceptance on the ground.

- Willingness to fully hand over all deliverables to the water utility upon project completion-the project result is a WSP that will be owned and maintained by the partner utility in the long term.

- Ability to work around WSP's start and stop phases as the project progresses. Technical assistance (TA) staff that have limited availability are probably not suitable to provide such support.

In applying the terms of reference (TOR), the following points are worth noting:

- It is essential that the preliminary drinking-water quality risk assessment and the related review of the design of the control measures be completed as part of the feasibility study and before the final design is completed. It is possible that inadequately controlled risks will be identified during the risk assessment which will influence the final design. Similarly, it is possible that institutional capacity limitations will be identified during the detailed review of the control measures which will also influence the final design. The draft risk assessment and control measure components of the preliminary WSP can take place as part of the technical assessment stage of the project appraisal phase. 
- It is important to ensure that local, practical operational knowledge is gathered as part of the development of the preliminary WSP process. Therefore, at least the local water utility and potentially other key local stakeholders need to be fully involved in its development.

- It is important to ensure a full, frank, and independent assessment of the risks to water quality and of the ability of the designed control measures to adequately manage those risks. The WSP process would be objectively and independently facilitated by a suitably experienced technical assistant reporting directly to the ADB project manager, and/or overseen by an independent, technically competent observer.

- There is some significant technical content associated with WSPs. It is important that a WSP technical assistant is conversant with the technical concepts, terminology, and jargon associated with WSPs as used in the local context. If translation support were required, the translator would ideally be familiar with urban water supply systems in the local context.

- There may be value in partnering with comparable water supply projects that operate in similar contexts elsewhere. For many projects, a reasonably comparable situation may exist where a WSP is already in place. Partnering and mentoring can often be arranged in such situations, and ADB and $\mathrm{WHO}$ can often assist in facilitating such relationships.

- There is a wide range of WSP (and equivalent) guidance documents published around the world. These include various versions of the WHO WSP, and many jurisdictions have their own WSP guidelines. Some counterpart and donor agencies have their WSP guidance documents. It is important to clarify what is meant by a WSP by referring to the specific WSP documents used to guide the WSP. Furthermore, various interpretations can be made of the same documents. If this is not clear, it is very difficult to pass or fail the WSP technical personnel based on what they deliver.

- It is also important to clarify which water quality standards, and which aspects of those standards, the water supply should meet. All WSPs must focus first and foremost, and sometimes exclusively, on microbial quality since this is the principal risk factor for public health and one of the hardest factors to measure and manage. In fact, the main purpose of introducing WSPs was to manage microbial water quality. Microorganisms are hazardous after just moments of exposure; yet microbial test results are not available for days to weeks. Furthermore, most pathogens of concern cannot be tested in water. Monitoring and managing the control processes (e.g., filtration and chlorination processes), ideally through continuous monitoring with automated and instantaneous cessation of supply in the event of process failure, is the only reliable way of ensuring microbial water safety. However, WSPs can be used to manage chemical, physical, and radiological health hazards, as well as hazards of aesthetic relevance and other aspects of customer acceptability. This is very relevant because a WSP's scope, and therefore the work of the TA staff, is very variable along with this decision.

- The time frame, project stages, and notice to be given for each phase need to be very clear to allow any interested party to ensure their full availability to the project at all key stages. Similarly, in general, WSPs start and stop in phases as the project progresses, and it is important that this is understood by the WSP technical personnel and that the person can work around that. The extent of notice to be given needs to be clear-some TA staff can be available at a moment's notice, others require extensive notice, and others are only available at specific periods, e.g., during student vacations (academic workers).

- It is not necessary to set out each WSP step since they are clearly set out already in WSP guidance. However, it is important to decide on the reporting and delivery milestones and on highlighting those. It is also important to indicate the time required for specific actions, such as workshops, that will inevitably require a number of days. 
- It is useful to indicate the approximate budget available for travel-related expenses and personal remuneration.

- The details of the specific project(s), in which the WSP technical personnel are to be engaged, can often be referenced since they would already be set out. Therefore, factors such as location, project type, key stakeholders, and the high-level project plan would already be available and can simply be attached rather than reiterated in the TOR.

- The method of performance assessment would be made clear to avoid problems later on if the appointed WSP technical personnel and the ADB representative have different views on the project's completion. There are a variety of means for assessing WSP performance, and the choice of assessment method can influence how a WSP is structured. The difficulty is that although a WSP is a structured, it is not straightforward in assessing whether a WSP is appropriate or adequate. In general, a degree of professional judgment is required, and a third party WSP expert might be needed to complete the assessment. But regardless of how the assessment is undertaken, the approach needs to be as clear as practicable.

Note that the TOR do not have to be highly specific in relation to items that are already specified elsewhere, provided that the TOR identify precisely which document contains those details and where to find those items. In summary, the key items that need to be specified are those that help define the scope of the WSP since that can vary greatly and will, therefore, affect the estimated fee that a WSP technical personnel would charge to complete the project. 


\section{PART 4}

\section{REFERENCES AND SUPPORTING DOCUMENTS}

Wocument
World Health Organization (WHO) Guidelines for Drinking-water Quality
http://www.who.int/water_sanitation_health/publications/2011/dwq_guidelines/en/
WHO. 1997. Guidelines for drinking-water quality: Volume 3: Surveillance and control of
community supplies. 2nd ed. Geneva.
http://www.who.int/water_sanitation_health/dwq/gdwqvol32ed.pdf

\section{Water Safety Plan guidelines}

Water safety Plan Manual (2006)

http://www.who.int/water_sanitation_health/dwq/manual.pdf

WHO. 2012. Water safety planning for small community water supplies: Step-by-step risk management guidance for drinking-water supplies for small communities. Geneva. http://www.who.int/water_sanitation_health/publications/small-comm-water_ supplies/en/

Training Workbook on Water Safety Plans for Urban Systems (2008)

http://www.wpro.who.int/publications/PUB_9789290614029/en/

Capacity Training on Urban Water Safety Planning - Training Modules (2016)

http://www.searo.who.int/entity/water_sanitation/documents/WSP_Training_ Modules/en/

Godfrey, S. and Howard, G. 2004. Water Safety Plans (WSP) for Urban Piped Water Supplies in Developing Countries. Water, Engineering and Development Centre, Loughborough University, UK.

http://www.watersanitationhygiene.org/References/EH_KEY_REFERENCES/

WATER/Water\%20Quality/Water\%20Quality\%20Surveillance/Water\%20

Safety\%20Plans\%20(WEDC).pdf

Water and Sanitation Program. 2010. Water Safety Plans for Rural Water Supply in India: Policy Issues and Institutional Arrangements.

http://www.wsp.org/wsp/sites/wsp.org/files/publications/Water-Safety-Plans-ruralwater-supply-India.pdf

Village Water Safety Planning: Sikkim Rural Drinking-water http://www.wsp.org/wsp/sites/wsp.org/files/publications/SIKKIM_Training_Manual. pdf

Main Focus

Organizations

Overarching WHO

drinking-water

guidance

Special WHO guidance for community water supplies
WHO Headquarters.

Water, Sanitation,

Hygiene and Health

Unit

WHO Headquarters.

Water, Sanitation,

Hygiene and Health Unit
Overarching advice on implementing the WSP approach

Special WSP guidance for community water supplies

Provides specific guidance on adopting WSPs in urban systems

Provides training support for WSPs

Guides user through the process of developing WSPs

Outlines the key principles of water safety planning for rural water supply in India

This training manual describes how to prepare a village WSP.
WHO Headquarters. Water, Sanitation, Hygiene and Health Unit

WHO Headquarters. Water, Sanitation, Hygiene and Health Unit

WHO's Western Pacific Regional Office

WHO's South-East

Asian Regional Office

Loughborough

University and

the Department

for International Development of the United Kingdom

Water and Sanitation Program

State Institute of Rural Development and Water and Sanitation Program 
Table continued

\begin{tabular}{|c|c|c|}
\hline Document & Main Focus & Organizations \\
\hline $\begin{array}{l}\text { WHO and International Water Association (IWA). 2013. Water Safety Plan Quality } \\
\text { Assurance Tool. } \\
\text { http://www.wsportal.org/templates/ld_templates/layout_33212. } \\
\text { aspx?Objectld=20686\&lang=eng }\end{array}$ & $\begin{array}{l}\text { Example of WSP } \\
\text { assessment tool }\end{array}$ & $\begin{array}{l}\text { WHO's Geneva Office } \\
\text { for Water, Sanitation } \\
\text { and Health with IWA, } \\
\text { Netherlands }\end{array}$ \\
\hline $\begin{array}{l}\text { WHO and IWA. 2015. A practical guide to Auditing water safety plans. } \\
\text { http://www.who.int/water_sanitation_health/dwq/audit-for-wsp.pdf }\end{array}$ & $\begin{array}{l}\text { Example of WSP } \\
\text { auditing tool }\end{array}$ & $\begin{array}{l}\text { WHO's Geneva Office } \\
\text { for Water, Sanitation } \\
\text { and Health with IWA, } \\
\text { Netherlands }\end{array}$ \\
\hline $\begin{array}{l}\text { WHO and IWA. Water Safety Portal. } \\
\text { http://www.wsportal.org/ibis/water-safety-portal/eng/home }\end{array}$ & $\begin{array}{l}\text { Examples of WSP case } \\
\text { studies and tools }\end{array}$ & $\begin{array}{l}\text { WHO's Geneva Office } \\
\text { for Water, Sanitation } \\
\text { and Health with IWA, } \\
\text { Netherlands }\end{array}$ \\
\hline \multicolumn{3}{|l|}{ Pathogen reduction guidelines } \\
\hline $\begin{array}{l}\text { Environmental Protection Agency. 2006. Long Term } 2 \text { Enhanced Surface Water } \\
\text { Treatment Rule (LT2ESWTR), Cincinnati, United States of America. } \\
\text { https://www.epa.gov/dwreginfo/surface-water-treatment-rules }\end{array}$ & $\begin{array}{l}\text { Pathogen reduction } \\
\text { requirements for the } \\
\text { United States }\end{array}$ & $\begin{array}{l}\text { United States } \\
\text { Environmental } \\
\text { Protection Agency }\end{array}$ \\
\hline $\begin{array}{l}\text { Water Services Association of Australia. 2015. Drinking Water Source Assessment and } \\
\text { Treatment Requirements: Manual for the Application of Health-Based Treatment Targets. } \\
\text { Melbourne, Australia. } \\
\text { https://www.wsaa.asn.au/publication/health-based-targets-manual }\end{array}$ & $\begin{array}{l}\text { Pathogen reduction } \\
\text { requirements for } \\
\text { Australia }\end{array}$ & $\begin{array}{l}\text { Water Services } \\
\text { Association of Australia }\end{array}$ \\
\hline $\begin{array}{l}\text { Ministry of Health. 2008. Drinking-water Standards for New Zealand 2005. Revised } \\
\text { 2008. Wellington, New Zealand. } \\
\text { https://www.health.govt.nz/publication/drinking-water-standards-new-zealand- } \\
\text { 2005-revised-2008 }\end{array}$ & $\begin{array}{l}\text { Pathogen reduction } \\
\text { requirements for New } \\
\text { Zealand }\end{array}$ & $\begin{array}{l}\text { New Zealand Ministry } \\
\text { of Health }\end{array}$ \\
\hline $\begin{array}{l}\text { Health Canada. 2013. Guidance on the Use of the Microbiological Drinking Water } \\
\text { Quality Guidelines. Ottawa, Canada. } \\
\text { http://www.hc-sc.gc.ca/ewh-semt/pubs/water-eau/micro/index-eng.php }\end{array}$ & $\begin{array}{l}\text { Pathogen reduction } \\
\text { requirements for } \\
\text { Canada }\end{array}$ & Health Canada \\
\hline \multicolumn{3}{|l|}{ Asian Development Bank (ADB) guidance } \\
\hline $\begin{array}{l}\text { ADB. 2016. Guidelines for Preparing a Design and Monitoring Framework. Manila. } \\
\text { https://www.adb.org/sites/default/files/institutional-document/32509/guidelines- } \\
\text { preparing-dmf.pdf }\end{array}$ & $\begin{array}{l}\text { Provides support for } \\
\text { setting up the design } \\
\text { and monitoring } \\
\text { framework for projects }\end{array}$ & $A D B$ \\
\hline
\end{tabular}




\section{Water Safety Planning for Urban Water Utilities Practical Guide for ADB Staff}

The World Health Organization estimates that contaminated drinking water causes 502,000 diarrheal deaths each year and that by 2025 , half of the world's population will be living in water-stressed areas. The Asian Development Bank (ADB) is committed to provide safe drinking water throughout Asia and the Pacific. This handbook was prepared for $A D B$ project officers as a guide toward efficient integration of the Water Safety Plan (WSP) approach into ADB's urban water operations. The WSP is a tool that assists water suppliers and other stakeholders to identify and prioritize system needs. This publication provides a step-by-step guide on developing and implementing a WSP using guidelines, templates, evaluation criteria, and terms of reference for early technical assessments and project preparatory technical assistance stages.

\section{About the Asian Development Bank}

$A D B$ 's vision in an Asia and Pacific region free of poverty. Its mission is to help its developing member countries reduce poverty and improve the quality of life of their people. Despite the region's many successes, it remains home to a large share of the world's poor. ADB is committed to reducing poverty through inclusive economic growth, environmentally sustainable growth, and regiona integration.

Based in Manila, ADB is owned by 67 members, including 48 from the region. Its main instruments for helping its developing member countries are policy dialogue, loans, equity investments, guarantees, grants, and technical assistance.

\section{Securing Water, Sustaining Futures}

